\title{
Chapter 3 \\ Behaviour and Population Dynamics of Entomopathogenic Nematodes Following Application
}

\author{
Christine T. Griffin
}

\subsection{Introduction}

Entomopathogenic nematodes (EPN) of the genera Steinernema and Heterorhabditis are widely used in inundative biological pest control programmes. It has long been recognised that increased understanding of the ecology of EPN is important for better predictions of field performance and environmental risk (Ehlers \& Hokkanen, 1996; Gaugler, Lewis, \& Stuart, 1997). Increasingly, EPN are also finding a place as model organisms for fundamental studies in behavioural ecology and evolutionary biology (Campos-Herrera, Barbercheck, Hoy, \& Stock, 2012). In this chapter, I consider the fate of EPN used in biocontrol, focussing largely on inundative application to soil. The aim is to provide an overview of the transformation of a biotechnological product to an ecological entity, rather than a review of this rather broad topic. There are already several extensive reviews relevant to the subject, including EPN behaviour and their fate in soil (e.g. Griffin, 2012; Kaya, 2002; Lewis, Campbell, Griffin, Kaya, \& Peters, 2006; Stuart, Barbercheck, Grewal, Taylor, \& Hoy, 2006; see also Chap. 4). It should be noted that, while the concept of this chapter is to follow the fate of commercially produced EPN when applied to soil, many of the laboratory studies cited have used nematodes produced in insects rather than taken from commercial formulations.

In considering the fate of EPN we can focus on the population or the individual. Smits (1996) proposed a useful model for considering the fate of the applied population, with an initial period of rapid decline, a more gradual decrease in numbers, followed by maintenance at a low level through periodic recycling (Fig. 3.1). Later studies support these general trends. Different factors are likely to

C.T. Griffin $(\square)$

Department of Biology, Maynooth University, Maynooth, County Kildare, Ireland

e-mail: Christine.griffin@nuim.ie

R. Campos-Herrera (ed.), Nematode Pathogenesis of Insects and Other Pests,

Sustainability in Plant and Crop Protection 1, DOI 10.1007/978-3-319-18266-7_3 


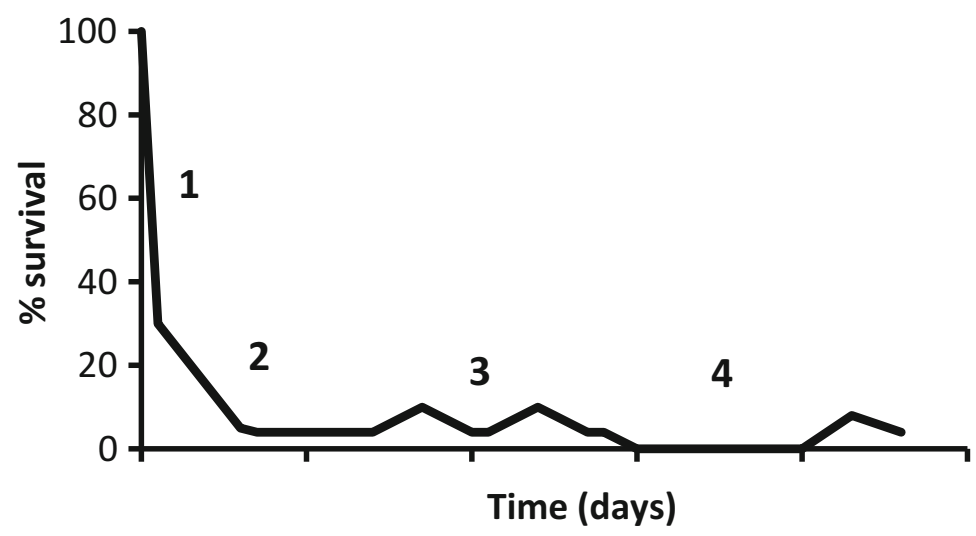

Fig. 3.1 Post-application persistence of entomopathogenic nematode populations, after Smits (1996), showing a rapid decline immediately after application (1) followed by a more gradual decline of the applied infective juveniles (2) and eventual maintenance of the population through recycling (3). Populations may become undetectable (4) due to low numbers of infective juveniles free in soil and recover as new hosts are infected or juveniles emerge from previously infected hosts

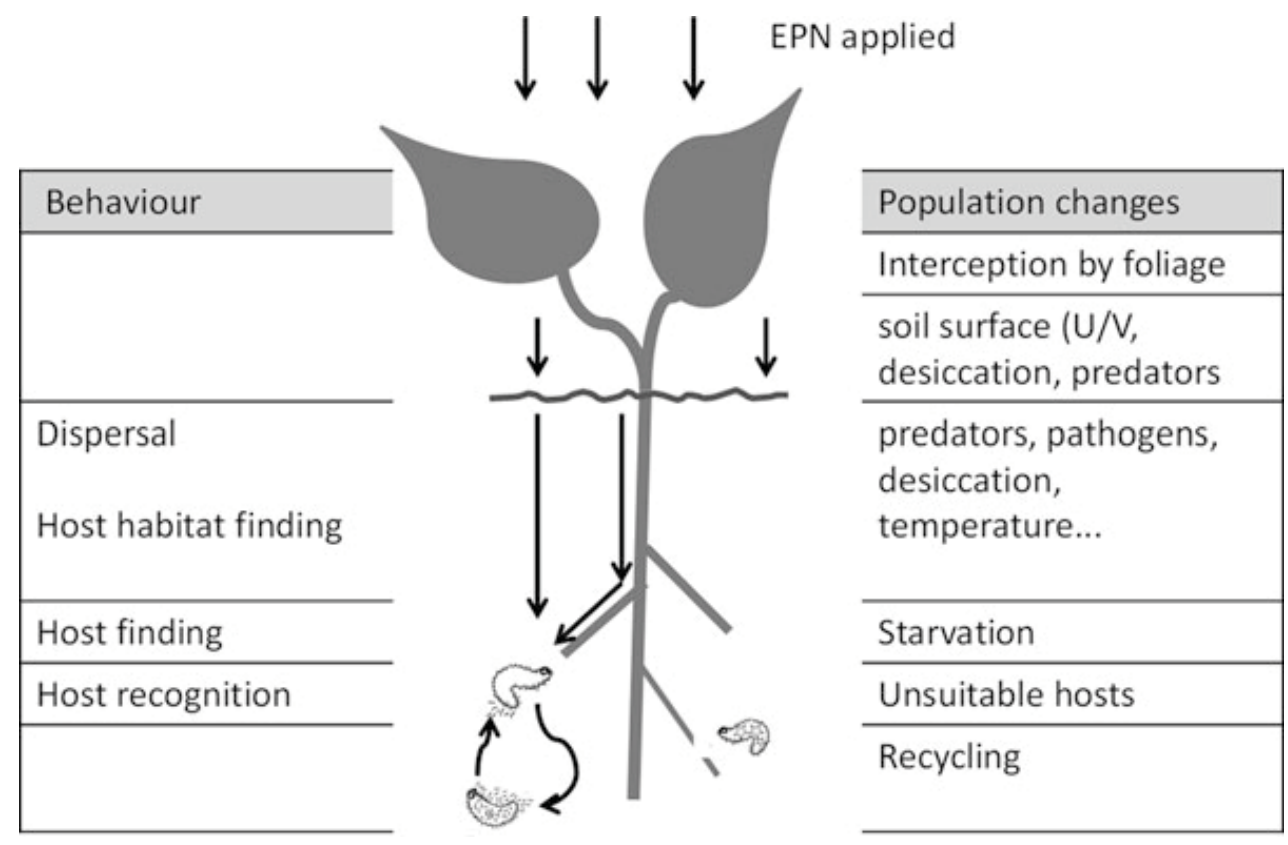

Fig. 3.2 Schematic of behaviour and fate of entomopathogenic nematodes following application to soil for biocontrol

be important at each phase - for example, acute mortality factors such as ultraviolet light, desiccation or predation may be important in the first phase, with starvation, pathogens or invasion into hosts resulting in disappearance of IJs later, while availability of suitable hosts will be critical for longer term population persistence (Fig. 3.2, right panel). While Smits' scheme charts the fate of the population, a fuller appreciation of population dynamics and pest suppression can be obtained by focussing on the individual infective juveniles (IJs) that make up the population. At the individual level, the host-finding behaviour of a parasite can be considered as 
a hierarchical series of steps including host habitat finding, host finding and host selection (Fig. 3.2, left panel). This scheme, developed for trematodes (Wright, 1959), also fits EPN (Campbell \& Lewis, 2002) and will be used here.

\subsection{Fate of the Inoculum: Death or Dispersal}

For biocontrol purposes, nematodes are typically applied inundatively in high numbers (at least $2.5 \times 10^{9} \mathrm{IJ} /$ /hectare, Shapiro-Ilan, Han, \& Dolinski, 2012). Their fate will depend on a multitude of interacting factors, including soil conditions, crop type and the quality of the applied inoculum. While the scale varies depending on conditions at the application site and the species or population of EPN, in general the scheme represented in Fig. 3.1 describes the fate of the population, with an initial dramatic decline immediately after application (Phase 1 in Fig. 3.1). This rapid decline, with losses varying between 40 and $90 \%$ within hours or days of application, has been attributed to inactivation of IJs by ultraviolet light and desiccation at the soil surface (Smits, 1996), but predation by collembolans and mites may also be important at this stage (Wilson \& Gaugler, 2004). Those nematodes that move into soil will be protected from UV, but still vulnerable to abiotic stressors such as desiccation and temperature extremes as well predators and pathogens such as nematode trapping fungi (reviewed by Kaya, 2002 and Chap. 4 in this volume). These mortality factors will contribute to the more gradual decline over succeeding weeks (Phase 2 in Fig. 3.1), but during this phase, starvation will become an additional mortality factor. Infective juveniles do not feed, relying on energy reserves of lipid (mainly triglycerides) and glycogen (Fitters, Patel, Griffin, \& Wright, 1999; Patel, Stolinski, \& Wright, 1997; Patel \& Wright, 1997). Under ideal conditions, individual IJs can survive for months but become visibly lighter as lipid reserves are used up, and eventually die of starvation (Fitters \& Griffin, 2006; Hass, Downes, \& Griffin, 2002; Patel et al., 1997). Physical soil parameters, especially temperature, moisture and texture influence survival of IJs that have reached the soil (Kaya, Gaugler, \& Kung, 1990; Kung \& Gaugler, 1991; Molyneux, 1985). Soil factors interact - for example, Pilz et al. (2014) point out that light sandy soils will only favour persistence as long as moisture is not a limiting factor, but in drier regions sandy soils will be subject to desiccation which is inimical to EPN survival. Extreme high temperatures are lethal (Shapiro, Glazer, \& Segal, 1996; Somasekhar, Grewal, \& Klein, 2002) but permissive temperatures also impact on survival by influencing respiration and motility and hence the rate at which energy reserves are depleted (Andalo, Moino, Maximiniano, Campos, \& Mendonca, 2011). Most studies of post-application persistence of EPN do not distinguish between the survival of applied IJs and replenishment of the population by recycling, but Preisser, Dugaw, Dennis, and Strong (2005) found that IJs of Heterorhabditis marelatus Liu and Berry (Rhabditida: Heterorhabditidae) survived in the field for at least a year in the absence of hosts. 
Survival of applied IJs will be influenced by the quality of the nematodes at time of application - a product of culture and storage conditions - as well as the treatment of the IJs during application (Grewal, 2002; Grewal \& Peters, 2005). Genetic quality of the master stock, as well as chemical and physical conditions during production, harvesting, formulation and storage all impact on the quality of the applied inoculum (reviewed by Grewal \& Peters). They affect the proportion of IJs retaining bacteria and the number of bacteria per IJ, as well as the quality of the IJs' energy reserves; these in turn influence virulence and the potential for survival of the IJs. Lipid reserves may be depleted during transport and storage, particularly if temperature deviates from the species-specific survival optimum (Grewal). At time of application, IJs may be damaged by exposure to high temperature or UV or by shear forces in the application equipment (Wright, Peters, Schroer, \& Fife, 2005). Stresses encountered before application may weaken the IJs and contribute to the initial decline in numbers.

Crop type influences both the number of IJs reaching the soil and their fate in the soil. The percentage of Heterorhabditis bacteriophora Poinar (Rhabditida: Heterorhabditidae) IJs reaching soil level immediately after spraying ranged from 5 to $6 \%$ in dense canopy crops (oilseed rape and lupine) to $77-78 \%$ in pasture and potatoes (Susurluk \& Ehlers, 2008). As this was measured by placing Petri dishes on the soil it probably overestimates the numbers actually reaching the soil in a pasture with dense thatch, which can form a significant barrier to EPN dispersal (Zimmerman \& Cranshaw, 1991). The number of IJs reaching the soil had no impact on short term establishment as detected by baiting one month postapplication (Susurluk \& Ehlers), and the authors suggested that additional IJs may have been washed from the plant canopy later. While IJs typically survive only short periods on exposed foliage (Schroer, Yi, \& Ehlers, 2005; Williams \& Macdonald, 1995), high humidity within a canopy and availability of water pooled in nodes of cereals and grasses may enable longer survival in certain circumstances (Fallon, 1998). In field experiments in turfgrass, whether a dramatic decline in recovery of EPN was observed or not varied depending on soil type, turfgrass management regime and time of year that the nematodes were applied, as well as EPN species (Ebssa \& Koppenhöfer, 2011). While recovery of all four species tested decreased with time, Steinernema carpocapsae (Weiser) Wouts, Mráček, Gerdin \& Bedding, (Rhabditida: Steinernematidae) was most likely to undergo a steep drop in the 4 days post-application. The authors attributed the rapid decline of $S$. carpocapsae to its tendency to remain near the soil surface where it would experience more extreme conditions. It should be noted that the cause of a decrease in numbers of EPN in the upper soil layer may be difficult to distinguish between downward migration and attrition of IJs (Elmowitz, Ebssa, \& Koppenhöfer, 2014). Crop factors that facilitate larger numbers of EPN reaching soil level may militate against longer term survival; thus, for example, the longer foliage of a golf course "rough" may mean fewer EPN reach the soil than on a closely mown green area, but the longer foliage may provide better protection from UV, high temperature and desiccation (Ebssa \& Koppenhöfer). 
Persistence of EPN in the field is usually monitored by baiting soil with insects and reporting the proportion of bait insects killed, though methods using qPCR have also been developed (Campos-Herrera et al., 2013; Duncan, Stuart et al., 2013). Even adaptations of the bait method to allow quantification (e.g. Elmowitz et al., 2014; Koppenhöfer, Campbell, Kaya, \& Gaugler, 1998) only detect IJs that are infective, and not necessarily total numbers of IJs surviving. Before eventual death by starvation, there is a decline in motility and ability to infect (Fitters \& Griffin, 2006; Hass, Griffin, \& Downes, 1999; Patel et al., 1997). In a laboratory study, Hass et al. showed that the baiting method (with nematodes quantified following dissection of bait insects) recovered only $20 \%$ of Heterorhabditis megidis Poinar, Jackson \& Klein (Rhabditida: Heterorhabditidae) from soil immediately after application compared to $56 \%$ recovered by Baermann funnel (a method that relies on activity of the IJs) and $82 \%$ by centrifugal floatation, a mechanical method that does not depend on nematode activity. The Baermann and baiting methods became even less efficient relative to mechanical extraction over the next 28 days, presumably due to declining activity of the IJs (Hass et al.). Detection by baiting gives an indication of the "killing power" of the soil, which is what matters in biocontrol; it can be argued that this is what matters in an ecological context also, as IJs that are not infective cannot reproduce. However, baiting may underestimate the persistence of ecologically relevant IJs if part of the population is temporarily non-infective (Bohan \& Hominick, 1996, 1997; Griffin, 1996).

Within-population heterogeneity in survivorship may have important consequences in determining extinction or persistence of a population (Bolnick et al., 2003; Dugaw \& Ram, 2011). Population numbers may drop dramatically, but a few individuals that survive (e.g. harsh conditions or periods without hosts) may be responsible for its recovery. Using a modelling approach, Dugaw and Ram showed that a population of $H$. marelatus IJs with individual variation in mortality rates had a good chance of surviving the necessary 5 months in soil until hosts became available, while a population of homogeneous individuals would face almost certain extinction. Demonstrated sources of variation in survivorship include variation in starting lipid reserves, and in the rate at which these lipids are depleted (Fitters \& Griffin, 2006; Patel et al., 1997). This heterogeneity in lipid utilisation, where a few individuals remain visibly dark and rich in reserves when others of the population are completely transparent and close to death by starvation, may be indicative of a "bet-hedging" strategy, where parents spread the risk so that at least some offspring survive (Fenton \& Hudson, 2002). Apart from genetic variation (Ehlers, Oestergaard, Hollmer, Wingen, \& Strauch, 2005; Shapiro, Glazer, \& Segal, 1997; Wang, Jung, Son, \& Choo, 2013), differences between individuals may arise due to varied conditions experienced during development. IJs emerging from a host at different times differ in size, infectivity and other behaviours (Lewis \& Gaugler, 1994; Nguyen \& Smart, 1995; Ryder \& Griffin, 2003), presumably due to differing conditions of nutrition experienced. Intrinsic (biotic) variation in the population will interact with micro-site variation in soil conditions such as moisture. 


\subsection{Foraging in Soil and the Root Zone}

While thousands of IJs emerge from an insect and miles of millons are applied to control pests, each acts as an individual in its search for a host. In the classic scheme of parasite host-finding developed for schistosomes (MacInnis, 1976; Wright, 1959), there is an initial dispersal phase when parasites move away from the natal host. This dispersal phase is characterised by random movement, though the parasite may also be responsive to signals from the environment that serve to bring it to the host habitat. Once in the host's habitat, the parasite may again move randomly until it encounters the host's "active space" (area of the habitat modified by the presence of the host - gradients of $\mathrm{CO}_{2}$, other chemicals, temperature) after which more directed host-searching along gradients brings the parasite to the host surface (McInnis). For EPN, the host's active space will frequently be chemical in nature (Dillman et al., 2012; Lewis et al., 2006), though vibrations (Torr, Heritage, \& Wilson, 2004) and fine-scale temperature gradients (Burman \& Pye, 1980; Byers \& Poinar, 1982) may also be effective components of the insect host active space.

As part of their transmission strategy, parasites may modify their behaviour spontaneously depending on their age, coinciding with the various stages of hostfinding (Haas, 2003). This is best documented for trematode miracidia, which for the first few hours after hatching are unresponsive to their snail host while moving rapidly in straight lines (Sukhdeo \& Sukhdeo, 2004). There is evidence of a similar phasing of activities in certain heterorhabditids (Dempsey \& Griffin, 2002; Griffin, 1996). The distance H. megidis IJs migrated in sand declined with age, while infectivity (measured as the proportion of IJs entering an insect) increased, suggesting that IJs are initially in a dispersive phase of high mobility and low interest in infecting hosts that should serve to take them away from competitors, and that they subsequently become more motivated to infect (Dempsey \& Griffin; Griffin). The behaviour of parasite infective stages is shaped by natural selection to increase the probability of encountering a host, and changes in infectivity and of motility are part of this "optimal transmission strategy" for EPN. Movement is essential for host location, but brings starvation closer and also increases the risk of encountering pathogens. The IJ is thus faced with a classic trade-off situation (McNamara \& Houston, 1991), where the optimum strategy for the IJ depends on the characteristic abundance of both hosts and pathogens. In habitats where host abundance is seasonal, the IJ may do best by becoming inactive on reaching a critical starvation level (indicating a failure to find a host) to conserve energy until hosts are again available. We expect the behavioural strategy of native EPN to be adapted to local conditions, while that of applied IJs may not be such a good fit.

A distinction can be made between EPN species based on modes of foraging (Campbell \& Gaugler, 1997; Grewal, Lewis, Gaugler, \& Campbell, 1994; Lewis, Grewal, \& Gaugler, 1995; reviewed by Lewis et al., 2006). While Heterorhabditis spp. tend to adopt cruise foraging, Steinernema species vary along a continuum from cruise to ambush, with species such as Steinernema feltiae (Filipjev) Wouts, Mráček, Gerdin \& Bedding (Rhabditida: Steinernematidae) said to employ an 
intermediate foraging strategy (Campbell \& Gaugler). Cruise foragers move actively through soil, and use distant volatile cues to assist in host-finding. In ambush foragers, notably S. carpocapsae, and Steinernema scapterisci Nguyen \& Smart (Rhabditida: Steinernematidae) most IJs remain near the soil surface (Georgis \& Poinar, 1983) where they lift their body into the air, facilitating attachment to passing insects (Campbell \& Gaugler, 1993). These IJs exhibit jumping behaviour, which is also believed to facilitate attachment to hosts (Campbell \& Kaya, 1999; Campbell, Lewis, Stock, Nadler, \& Kaya, 2003). For ambushers, volatiles are said to be relatively unimportant in host-finding at a distance (Grewal et al.; Lewis et al.), though ambush species are attracted to both $\mathrm{CO}_{2}$ and more specific host odours (Dillman et al., 2012). Cruise foragers are expected to infect less mobile hosts underground while ambushers are considered to be more successful at infecting mobile, surface dwelling hosts (Gaugler et al., 1997). While there are definite differences in behaviour between EPN species traditionally classified as ambushers and those classified as cruisers (e.g. nictation and jumping are expressed by "ambush" species), it is becoming increasingly clear that $S$. carpocapsae, an ambusher, can find and infect relatively immobile insects at considerable distances from the point of application (de Altube, Strauch, de Castro, \& Pena, 2008; Dembilio, Llacer, de Altube, \& Jacas, 2010; Dillon, Ward, Downes, \& Griffin, 2006), prompting some to question the usefulness of the classification (Wilson, Ehlers, \& Glazer, 2012).

Even true sit-and-wait foragers must disperse, and dispersal is an essential phase preceding and possibly interspersed with bouts of host finding. S. carpocapsae IJs move both vertically, reaching depths of $15-20 \mathrm{~cm}$ in soil (Ferguson, Schroeder, \& Shields, 1995) and laterally: about $4 \%$ of $S$. carpocapsae IJs ("sprinters") dispersed faster than the fastest H. bacteriophora (Bal, Taylor, \& Grewal, 2014). Dispersal by $S$. carpocapsae IJs appears to be strongly influenced by substrate, being much greater in pure peat than in pure sand (Kruitbos, Heritage, Hapca, \& Wilson, 2010). In nature, IJs emerge in their thousands from the depleted natal host and should have experienced strong selection to move away from these overcrowded conditions.

\subsubsection{Dispersal and Host Finding in Soil}

Active dispersal by IJs after inundative application is usually a few centimetres per day and limited to a scale of meters overall (Downes \& Griffin, 1996; Poinar \& Hom, 1986). As for survival, abiotic factors strongly influencing EPN dispersal and hostfinding include soil texture, moisture and temperature. In general, light-textured (sandy) soils favour nematode movement (Georgis \& Poinar, 1983; Koppenhöfer \& Fuzy, 2006). Early experiments with plant parasitic nematodes (e.g. Wallace, 1968) illustrate how nematodes move through the water film coating soil particles, and emphasised that what determines the suitability for nematode movement is not the proportions of different sized particles per se, but the size of pores relative 
to the nematodes, and that it is the matric potential (not total water content) that is important, as this is related to the surface tension and water films within the soil. The bulk density or degree of compaction is also important, as it affects the soil pores. Portillo-Aguilar, Villani, Tauber, Tauber, and Nyrop (1999) varied both texture and bulk density and found that rates of movement and infection by three EPN species were strongly correlated with the amount of soil pore space with dimensions similar to or greater than the diameter of the nematodes. The size of particles and their packing determine the channels open to nematode movement, as well as the soil moisture profile and the diffusion of oxygen. While moisture is essential for nematode movement and survival, in saturated soils microbial activity results in anaerobic conditions which may render nematodes quiescent. In fertile soils, the particles are aggregated together in the form of crumbs, which increase the total pore space in the soil, allowing good aeration and drainage (Wallwork, 1970). Burr and Robinson (2004) suggest that nematodes with mean lengths of around $1,000 \mu \mathrm{m}$ (the typical length for EPN IJs) may be adapted to use channels provided by roots and insects, rather than the soil interstices that are better suited to smaller nematodes of around $400 \mu \mathrm{m}$.

Consideration of the effects of soil type on EPN usually focusses on the mineral component - proportions of sand, silt and clay particles. Movement in organic media has received less attention. Many potting media, and peat soils such as those used for coniferous forestry in northern temperate regions, are composed largely of organic matter. EPN can disperse and find hosts in these highly organic media (Ansari \& Butt, 2011; Nielsen \& Lewis, 2011). Kruitbos et al. (2010) compared pure sand and pure peat as media for EPN dispersal and host-finding, and found contrasting responses for two species; the ambush forager $S$. carpocapsae displayed host-finding behaviour in peat but not in sand, while the reverse was true for the cruise forager $H$. megidis. S. carpocapsae also dispersed better in peat than in sand. The authors suggested that the poor performance of H. megidis in peat was due to adsorption onto the organic matter of the host volatiles that are used by cruiser species to locate their host. However, in organic media including peat, $H$. megidis and two other heterorhabditids showed superior host finding compared to S. carpocapsae (Ansari \& Butt). In the field, both S. carpocapsae and the cruiser Heterorhabditis downesi Stock, Burnell \& Griffin (Rhabditida: Heterorhabditidae) performed better in peat than in mineral soils in field trials against pine weevil (Williams, Dillon, Girling, \& Griffin, 2013). Movement and host finding of EPN in organic media is worthy of more attention.

Random movement may be important in bringing a parasite into the zone in which signals (from host or host habitat) can be effective for directing movement (MacInnis, 1976). IJs will encounter stimuli that initiate directed search either in response to the host itself, or roots as indicator of likely host habitat. The importance of directed movement in bringing IJs to their hosts should not be overestimated. In laboratory assays, where single stimuli are presented in simplified media such as sterile sand, it is easy to demonstrate that EPN follow gradients or accumulate at stimulus source. In nematodes, directed movement may be superimposed on a large random movement component, and directed movement may be only partially 
substituted for random movement even in a gradient (Hunt, Wall, DeCrappeo, \& Brenner, 2001). Carbon dioxide is one of the main attractants identified for EPN but biologically active soil will be full of sources of it, making it unreliable for finding insects at a distance in such soils. However, following a $\mathrm{CO}_{2}$ gradient is likely to bring nematodes to plant roots (Dusenbery, 1987), where potential hosts might then be found by moving along the roots randomly and/or in response to further directional signals operating over a shorter scale. $\mathrm{CO}_{2}$ may be seen as a response-activator that alerts EPN to the presence of living organisms and may enhance responsiveness to other more specific cues (Turlings, Hiltpold, \& Rasmann, 2012) that are discussed in more detail below.

\subsubsection{Dispersal and Host-Finding in the Root Zone}

Many of the hosts naturally utilized by EPN or targeted by their application are root-feeding insects and hence much of IJ behaviour takes place in the context of the rhizosphere. Plant roots may affect the dispersal and host-finding of EPN in a number of ways: by attracting nematodes into the root zone, where hosts are located, by effects on host-finding within the root zone itself, and by influencing conditions for survival. Roots play a major role in shaping the soil environment, influencing the physical structure, $\mathrm{pH}$, water and oxygen availability, as well as gradients of information-rich chemicals (Dini-Andreote \& van Elsas, 2013; Hinsinger, Bengough, Vetterlein, \& Young, 2009). While the traditional view is that roots dry the surrounding soil by the uptake of water, the effects of plants on the availability of water in soil are complex (Carminati et al., 2011). Redistribution of soil water from moist deep layers to drier surface layers (hydraulic lift) by citrus roots enhanced survival of Steinernema diaprepesi Nguyen \& Duncan (Rhabditida: Steinernematidae) (Duncan \& McCoy, 2001). Similarly, the maintenance of a moist microclimate by the taproot of bush lupine facilitated survival of $H$. marelatus during dry conditions (Preisser, Dugaw, Dennis, \& Strong, 2006). Bal et al. (2014) reported that the presence of vegetation enhanced lateral dispersal of both $S$. carpocapsae and $H$. bacteriophora. The presence of roots in soil increased the rate of infection by EPN of non-feeding trap insects (wax moths), but only at low root density (Choo \& Kaya, 1991), while high density of roots interfered with host finding (Choo, Kaya, Burlando, \& Gaugler, 1989). Similar effects were reported by Cutler and Webster (2003).

Roots alone are attractive to EPN (Bird \& Bird, 1986; Hui \& Webster, 2000; Kanagy \& Kaya, 1996), but especially when wounded or fed on by insects (Boff, van Tol, \& Smits, 2002; Rasmann \& Turlings, 2008; van Tol et al., 2001; Wang \& Gaugler, 1998). Rasmann et al. (2005) reported that maize plants released (E)$\beta$-caryophyllene in response to feeding by larvae of corn rootworm Diabrotica virgifera virgifera Le Conte (Coleoptera: Chrysomelidae), and that this volatile was highly attractive to $H$. megidis. Other plant species also release volatiles from their roots in response to insect feeding, that attract EPN, though not all EPN respond 
similarly (Ali, Alborn, \& Stelinski, 2011; Hiltpold, Baroni, Toepfer, Kuhlmann, \& Turlings, 2010; Rasmann \& Turlings). Species with all categories of foraging strategy respond (Ali et al., 2011). Indeed, the same signal also attracted freeliving bacterial feeding nematodes that might compete with EPN for the cadaver as a resource (Ali, Campos-Herrera, Alborn, Duncan, \& Stelinski, 2013). That nematode-host specialization may be more important than foraging strategy is indicated by the fact that the response of $S$. diaprepesi to citrus roots damaged by its host Diaprepes abbreviatus L. (Coleoptera: Curculionidae) was stronger than that of other EPN species (Ali et al.).

If herbivore-induced volatile signals are a reliable indicator of host presence, then they could be considered to represent host "active space", while the root zone itself could be considered host habitat. Chemical enlargement of host active space can significantly increase the transmission success of parasites, putting hosts themselves under pressure to suppress the emission of attractants. Use by EPN of plant-derived signals would be particularly important in finding hosts that are otherwise unattractive, such as vine weevil Otiorhynchus sulcatus Fabricius (Coleoptera: Curculionidae) larvae (Boff, Zoon, \& Smits, 2001). However, the usefulness of the volatiles will vary depending on soil type and conditions; for example, being less effective in soil types with high levels of chemical activity (Turlings et al., 2012). Soil texture and moisture also affect diffusion of volatiles. For example, (E) $-\beta$-caryophyllene diffused readily through sand but diffusion was limited in more complex soils (Hiltpold \& Turlings, 2008). Although (E)- $\beta$-caryophyllene appears to diffuse in the gaseous phase, soil moisture facilitated diffusion probably by preventing its adsorption onto soil particles and/or loss by vertical diffusion, with higher water content required in soil than in pure sand (Hiltpold \& Turlings, 2008; Chiriboga, Jaffual, Campos-Herrera, Roëder, \& Turlings, 2014).

In addition to providing a source of attractant and/or confusing volatiles, roots of trees or other plants may provide EPN with a physical "routeway", facilitating their penetration deep into soil. The presence of plant material (twigs) significantly increased S. carpocapsae-induced mortality of large pine weevils Hylobius abietis L. (Coleoptera: Curculionidae) buried close to the base of the twigs (Ennis, Dillon, \& Griffin, 2010). Such routeways may be particularly important for ambush strategists such as $S$. carpocapsae by stimulating ranging search (Lewis, Gaugler, \& Harrison, 1993). Migration along roots provides a plausible explanation for the success of the ambush species $S$. carpocapsae against root-feeding insects (de Altube et al., 2008; Dillon et al., 2006; Jansson, Lecrone, \& Gaugler, 1993), despite its reputation for remaining at the soil surface and not responding directionally to volatiles. For example, $S$. carpocapsae can parasitize larvae and pupae of $H$. abietis under the bark of tree roots at depths of up to $40 \mathrm{~cm}$ in the soil (Dillon et al.) and has been used as part of an integrated population suppression strategy for this pest (Torr, Wilson, \& Heritage, 2005). Similarly, S. carpocapsae has provided up to $95 \%$ control of flat-headed root borer Capnodis tenebrionis L. (Coleoptera: Buprestidae) in roots of apricot trees (de Altube et al.). Even for those species that actively disperse through a soil matrix, searching along a root may be a particularly efficient way of arriving at root-feeding insects. Host-finding by the cruise-forager 
H. megidis was facilitated by a simple unbranched artificial root, but the effect was reduced as branching levels increased (Demarta, Hibbard, Bohn, \& Hiltpold, 2014). However, the addition of (E) $-\beta$-caryophyllene dramatically changed the results, with more EPN finding hosts where the most complex root models were present (Demarta et al.). Comparative studies on the relative importance for ambush and cruise foragers of roots in facilitating penetration into soil would be instructive, as would further investigations into the impact of root architecture and surface properties on EPN migration. Roots actively release exudates including mucins and secondary metabolites which may facilitate or inhibit movement of nematodes in intimate association with the root surface (Dini-Andreote \& van Elsas, 2013; Wuyts, Maung, Swennen, \& De Waele, 2006), but this has received little attention for nematodes of any kind.

Insect feeding on plants may result both in the release of volatiles and the propagation of vibrations. For cruise foragers such as heterorhabditids, attraction to roots on which insects are feeding may be largely due to allelochemicals released from the damaged plant, but ambushers such as $S$. carpocapsae are reported to respond poorly to distant volatile signals while searching (Lewis et al., 1995). Torr et al. (2004) showed that artificially-produced vibrations transmitted through peat were attractive to EPN including $S$. carpocapsae, and since acoustic stimuli produced by insects can be transmitted for up to $30 \mathrm{~cm}$ through soil (Mankin et al., 2000) they are potentially an important source of information for EPN.

\subsubsection{Host Recognition and Acceptance}

We assume that the behaviour of nematodes, as other animals, has been shaped by evolution so as to yield the highest number of surviving offspring. The critical choice of which host to invade, which determines both the quality and quantity of resources, and the availability of both mating partners and of competitors, is made by the IJ. Since the IJ will rarely be presented with a simultaneous choice of hosts, the decision can be thought of as a series of binary "invade/do not invade" decisions. Hosts of diverse species and developmental stage may be utilized, as well as already-infected and even dead hosts (Peters, 1996; San-Blas \& Gowen, 2008). Having arrived at an insect, the IJ must decide whether to attempt to enter or not (host recognition). For a nematode, entry into a host in which it cannot develop is a dead end, though this may fulfil the requirement for pest population reduction. Following attraction by volatile cues, host recognition based on contact insect cues may involve insect excretory products, cuticle or gut contents (Grewal, Gaugler, \& Lewis, 1993; Grewal, Gaugler, \& Selvan, 1993; Lewis, Ricci, \& Gaugler, 1996). Host recognition behaviour may predict the suitability of invertebrates as hosts: the behavioural recognition response of $S$. carpocapsae to various insect species was correlated with the level of nematode reproduction supported by the species, while non-insect arthropods stimulated no recognition response and were not susceptible to nematode infection (Lewis et al.). However, for a generalist species with a 
broad host range, such a matching between host acceptance and suitability for reproduction may be less than perfect unless there are some general cues that are reliable predictors of suitability or unsuitability. Unless unsuitable hosts are commonly encountered, selection for recognition will be weak. Maintenance of a weak recognition filter is of advantage in the long term, allowing new hosts to be added to the range, even if some mortality of individuals in unsuitable hosts results in the short term (Combes, 1991).

For any EPN-host interaction, there is an optimal infection rate. For most species of Steinernema, which reproduce by amphimixis, a minimum of two IJs must enter and develop in order for reproduction to be possible, while for Heterorhabditis a single IJ can colonise a host, as all develop into self-fertile hermaphrodites; a similar situation exists for Steinernema hermaphroditum Stock Griffin \& Chaerani (Rhabditida: Steinernematidae) (Griffin, O'Callaghan, \& Dix, 2001). However, it may take more than one or two IJs to overcome the host defences (Peters \& Ehlers, 1994). With increasing numbers, intraspecific competition for host resources results in lower reproductive output per invading founding adult (discussed later). Therefore, once the number of nematodes necessary for reproduction and/or hostkilling has entered, it is in the interests of the residents to deter further invasion. Glazer (1997) found that hosts injected with IJs of three Steinernema spp. became less attractive for invasion by conspecifics about 6-9 $\mathrm{h}$ later, and data indicated that the initial infection induced the release of a substance which reduced the subsequent invasion (Glazer). However, in several other studies IJs were attracted to and entered hosts that were already occupied by conspecifics, even to the point of overcrowding (Christen, Campbell, Lewis, Shapiro-Ilan, \& Ramaswamy, 2007; Lewis et al., 2006; Ramos-Rodriguez et al., 2007). Indeed, some species may even prefer to invade an already-killed host - for example, Steinernema riobrave Cabanillas, Poinar \& Raulston (Rhabditida: Steinernematidae) preferred wax moth larvae infected $24 \mathrm{~h}$ previously over an uninfected wax moth (Christen et al.). For an IJ with a short lifespan, limited locomotory ability and only one chance at infection, it may be better to invade a suboptimal host than to reject it and fail to find a better one, on the basis that some reproduction is better than none. Alternatively, a suboptimal host may be accepted because IJs do not recognise it as such, due either to lack of meaningful cues from the host or limited sensory abilities of the IJs.

In some species at least, it appears that the tendency to infect changes with time since emergence from the source cadaver - before the eventual decline in infectivity associated with ageing. There are two models of "phased infectivity": Bohan and Hominick $(1996,1997)$ described fluctuations in infectivity of S. feltiae and attributed it to a proportion of IJs switching between a non-infective and an infective state. Griffin (1996) described an increase in the infectivity of $H$. megidis in the initial weeks after emerging from the natal host and attributed it to a gradual change in infection tendency of individual IJs, rather than a switch between states (Dempsey \& Griffin, 2002; Griffin, 1996; Ryder \& Griffin, 2003). This is discussed more fully in Lewis et al. (2006). From the individual nematode's perspective, IJs that delay infectivity for some time during which they (or their competitors) 
migrate away from the natal host from which they have emerged en masse benefit by avoiding the overcrowding that otherwise might be expected in adjacent hosts (Dempsey \& Griffin), while for a parent, producing offspring that differ in their infection strategies may be an important adaptation to uncertain conditions such as host availability - a strategy of bet-hedging (Fenton \& Hudson, 2002). At a population level, where individuals are not all maximally infective at the same time there is greater probability of successful recycling of EPN (Shields, Testa, Miller, \& Flanders, 1999).

\subsection{Infection and Reproduction: Recycling in Targets and Non-target Hosts}

Following the initial decline in numbers of applied IJs, nematode populations may be boosted and maintained by recycling in target and non-target hosts (Phase 3, Fig. 3.1). According to Smits (1996) the population maintains a fairly stable level of "perhaps 10,000-40,000 nematodes $/ \mathrm{m}^{2}$ ". Most species of EPN can utilise a fairly broad range of hosts, and as more than 100,000 IJs can be produced from a single large host cadaver (Dutky, Thompson, \& Cantwell, 1964; Lindegren, Valero, \& Mackey, 1993; Shapiro-Ilan, Gaugler, Tedders, Brown, \& Lewis, 2002), a large population of susceptible insects can contribute significantly to EPN population numbers. A higher yield of IJs per available host also contributes to recycling success of applied EPN (Kim \& Alston, 2008).

The time scale over which recycling is detected varies from just 1 month (McGraw, Vittum, Cowles, \& Koppenhöfer, 2010) to several years (Dillon, Rolston, Meade, Downes, \& Griffin, 2008; Ferguson et al., 1995; Shields et al., 1999). Some agronomic systems are more conducive to nematode recycling than others. In field crops, the longest persistence by $H$. bacteriophora of 23 months was following application to beans followed in rotation by wheat with red clover as cover crop (Susurluk \& Ehlers, 2008). This was presumed to be due to reproduction in larvae of the bean weevil Sitona lineatus L. (Coloptera: Curculionidae) which were abundant in the bean crop and may have persisted in the clover (Susurluk \& Ehlers). Similarly, nematode incidence (percentage of soil cores with EPN) increased from spring to autumn in crops with high densities of potential hosts $-S$. lineatus in pea and Delia radicum L. (Diptera: Anthomyiidae) in cabbage (Nielsen \& Philipsen, 2004b). Availability of suitable insects and low disturbance by ploughing, harrowing or other soil movements were factors that favoured longer term EPN persistence (Susurluk \& Ehlers). Incidence of several species of EPN remained high for 2 years after application to tree stumps, only declining by year three, as the stumps became unsuitable for $\mathrm{H}$. abietis pine weevils, the target pest (Dillon, Rolston et al.). Infected pine weevils collected shortly after treatment yielded up to 98,000 IJs per insect (Dillon et al., 2006); estimations based on an average of 140 weevils per stump and $50 \%$ infection rate (Dillon et al., 2006), with a conservative 50,000 IJs produced per 
insect, indicate that recycling could theoretically replace the 3.6 million IJs applied per stump. Similarly, Taylor, Szalanski, Adams, and Peterson (1998) estimated that house fly maggots Musca domestica L. (Diptera: Muscidae) found at high density in cattle feedlots could sustain nematode populations at the $\mathrm{LC}_{99}$ level, even if only $1.5 \%$ of the maggots were infected. Stable ecosystems such as turfgrass or alfalfa are likely to favour longer term persistence, and applied EPN can persist for several years in these systems (Koppenhöfer \& Fuzy, 2009; Shields et al.); indeed, $S$. scapterisci became established in turf grass and pasture following its introduction into Florida, as was intended (Parkman \& Smart, 1996).

Non-target insects may also contribute to the persistence of EPN populations. For example, larvae, pupae and adults of the non-target longhorn beetle Rhagium bifasciatum Fabricius (Coleoptera: Cerambycidae) all supported reproduction of EPN applied against pine weevil, producing up to 140,000 IJs per insect (Harvey, Alameen, \& Griffin, 2012). In a field study, persistence of applied $S$. carpocapsae was positively correlated with abundance of tenebrionid beetles, indicating possible use of these beetles for recycling (Hodson, Siegel, \& Lewis, 2012). Non-target insects may be important as reservoir hosts for maintenance of EPN populations over periods where target host susceptible stages are absent.

The suitability of insects encountered in the field to support EPN reproduction will vary depending on factors such as the insect's diet and disease levels (Barbercheck, Wang, \& Hirsh, 1995; Randall, Cable, Guschina, Harwood, \& Lello, 2013). For example, about ten times as many $S$. carpocapsae IJs were produced from corn rootworm Diabrotica undecimpunctata L. (Coleoptera: Chrysomelidae) fed on corn than from those fed on bitter squash (Barbercheck et al.). The effect of host insect diet was less severe for H. bacteriophora, and Barbercheck et al. proposed that inhibition of Xenorhabdus symbiont by cucurbitacins, secondary plant compounds derived from bitter squash, was a factor in the reduced progeny production by $S$. carpocapsae in squash-fed rootworms. Cockroaches harbouring endemic low-virulence parasites (a gregarine) produced $50 \%$ fewer $S$. carpocapsae IJs, and this was attributed to a reduction in host lipid levels of up to $69 \%$ (Randall et al.). Since low virulence endemic parasites such as protozoa are extremely common in nature (Randall et al.), their prevalence may impact on the recycling potential of applied EPN.

EPN may also enter and reproduce in hosts that have been killed by other causes (Půža \& Mráček, 2010a; San-Blas \& Gowen, 2008), and San-Blas and Gowen suggest that EPN should be considered facultative scavengers rather than as obligate parasites. The extent to which freeze-killed insects could support nematode reproduction varied between species, from Heterorhabditis indica Poinar, Karunakar \& David (Rhabditida: Heterorhabditidae), which utilised hosts that had been dead for no more than 3 days, to Steinernema glaseri (Steiner) Wouts, Mráček, Gerdin \& Bedding (Rhabditida: Steinernematidae) which utilised hosts that had been dead for 10 days (San-Blas \& Gowen). The poorer scavenging potential of the two Heterorhabditis species than of the steinernemamids tested by San-Blas and Gowen may be due at least in part to the greater reliance of heterorhabditids 
on their symbiont (Han \& Ehlers, 2000). Insects such as wireworms (Elateridae) that are resistant to EPN when alive, may be readily utilised for reproduction when killed by other causes, and since wireworms can reach high densities of 400 individuals $/ \mathrm{m}^{2}$, dead individuals may represent a profitable resource for EPN (Půža \& Mráček 2010b), though in the field there will be competition with other scavengers and saprotrophs. EPN can also develop in hosts killed by several insecticides (Hara \& Kaya, 1983; Koppenhöfer, Cowles, Cowles, Fuzy, \& Kaya, 2003) and by parasitoids (Atwa, Hegazi, Khafagi, \& Abd El-Aziz, 2013; Mbata \& Shapiro-Ilan, 2010), and in moribund hosts infected by granulosis virus (Kaya \& Burlando, 1989). However, where the integrity of the host cuticle is compromised, development may fail. Insects infected with nucleopolyhedrosis virus have a fragile cuticle and when this ruptures, developing EPN may desiccate and die before reproduction (Kaya, 2002). Hosts that have been killed by other pathogens including Bacillus thuringiensis Berliner (Bacillales: Bacillaceae) and the entomopathogenic fungi Beauveria bassiana (Balsamo) Vuillemin (Ascomycota: Hypocreales) do not support nematode reproduction (Barbercheck \& Kaya, 1990; Kaya \& Burlando), and may be avoided by IJs (Barbercheck \& Kaya, 1991). Although application of EPN together with an entomopathogenic fungus such as Metarhizium or Beauveria may result in enhanced mortality of target pests in the short term (Anbesse, Adge, \& Gebru, 2008; Ansari, Shah, \& Butt, 2008; Shapiro-Ilan, Jackson, Reilly, \& Hotchkiss, 2004), a strategy of joint application has implications for the recycling potential of both the EPN and the fungus in the pest environment. Both nematode and fungus compete for the host; which of the agents is successful depends to large extent on the time difference in colonisation (Acevedo, Samuels, Machado, \& Dolinski, 2007; Barbercheck \& Kaya, 1990).

The host cadaver provides a protected environment for nematodes, and IJs may remain inside during adverse conditions such as desiccation and cold (Koppenhöfer et al., 1997; Serwe-Rodriguez, Sonnenberg, Appleman, \& Bornstein-Forst, 2004; Spence et al., 2011). When cadavers infected by each of four EPN species were incubated in dry soil for various periods of time and then rehydrated, IJs survived from 27 to 111 days, depending on species (Koppenhöfer et al.). Amongst the Steinernema species, those adapted to infect insects near the soil surface (S. carpocapsae) or from semiarid regions (S. riobrave) survived longer periods of desiccation than the temperate cruise forager $S$. glaseri. Koppenhöfer et al. hypothesised that the outer layer of the insect cuticle dried out first, and the desiccated layers reduced further drying of the cadaver. As free-living IJs are not well adapted to survival in dry soil, the cadaver may be important in allowing nematode populations to persist through dry periods (Půža \& Mráček, 2007), as also in survival of freezing. Cadavers frozen when adult S. carpocapsae or H. bacteriophora were present went on to produce IJs when returned to permissive conditions (Lewis \& Shapiro-Ilan, 2002). While EPN IJs are freeze tolerant (Brown \& Gaugler, 1996), the cadaver may provide a safer overwintering environment by providing protection not only against freezing but other abiotic and biotic dangers. 
During dry or cold periods that are not conducive to IJ dispersal and host-finding, the pool of free IJs in soil will decline without replenishment from additional cadavers. At such times, a large proportion of the EPN population may be contained in infected insects, and would not be detected by standard methods of baiting or extraction of soil-dwelling nematodes (Phase 4 in Fig. 3.1).

Nematodes emerging from hosts in which they recycled may differ significantly from the applied, mass produced nematodes in several ways (physiology, size, behaviour, rate and location of arrival in soil). Firstly, nematodes produced in insects may differ in quality from those produced in fermenters, though the nature of the difference may vary between EPN species (Dillon et al., 2006; Ebssa \& Koppenhöfer, 2012; Gaugler \& Georgis, 1991; Grewal, Converse, \& Georgis, 1999). Moreover, the species of insect in which they develop may influence the lipid content, virulence or reproductive capacity of EPN (Abu Hatab \& Gaugler, 1999; Abu Hatab, Gaugler, \& Ehlers, 1998; Shapiro-Ilan, Dutcher, \& Hatab, 2005). For example, $S$. glaseri and $H$. bacteriophora developing in Japanese beetle Popillia japonica Newman (Coleoptera: Scarabaeidae) and S. carpocapsae developing in pecan weevil Curculio caryae Horn (Coleoptera: Curculionidae) had higher lipid content than those developing in wax moths (Abu Hatab et al.; Abu Hatab \& Gaugler; Shapiro-Ilan et al.). Passage through pecan weevil did not affect virulence of steinernematids, but did reduce their subsequent reproductive capacity in that host, leading to the conclusion that the recycling potential of nematodes in that host would diminish over time (Shapiro Ilan et al.). In contrast, the pathogenicity of $S$. carpocapsae increased more than two-fold after two passages through gypsy moth Lymantria dispar L. (Lepidoptera: Lymantriidae) larvae and there was no reduction in progeny production in that host (Shapiro, Poinar, \& Lindegren, 1985). Small hosts may result in smaller IJs (Gouge \& Hague, 1995; Nielsen \& Philipsen, 2004a), which could be an advantage in infecting hosts that have small natural openings (Scheepmaker, Geels, Griensven, Van, \& Smits, 1998).

Even when all IJs were produced in the same conditions (e.g. wax moth hosts) the behaviour of EPN emerging from cadavers differs from that of IJs applied in aqueous suspension, with enhanced dispersal and infectivity reported for the former (Shapiro \& Glazer, 1996; Shapiro \& Lewis, 1999). This may either be due to physiological status of recently emerged IJs and/or the presence of host stimuli such as ammonia or pheromones stimulating dispersal (Kaplan et al., 2012; San-Blas, Gowen, \& Pembroke, 2008; Shapiro \& Glazer). At application time, nematodes are released all at once, while emergence from an insect cadaver can take place over days or weeks (Stuart, Lewis, \& Gaugler, 1996; Ryder \& Griffin, 2003), essentially a "slow release". IJs continued emerging from long horn beetle $R$. bifasciatum for at least 8 weeks (Harvey et al., 2012), which would provide increased chances of at least some of the IJs emerging at a time when suitable hosts were available. Cadavers from which IJs emerge will be located in the same area as other insects of the host species, giving them an advantage over surface-sprayed inoculum. The more cryptic the host, the greater the difference in search path between applied and recycled nematodes. For example, IJs emerging from infected pine weevil larvae will already 
be under the bark of tree stumps and roots, and at depths of up to $50 \mathrm{~cm}$ in soil (Dillon et al., 2006) and thus well placed for infecting any remaining live weevils.

\subsection{Competition and Cooperation: Effects on Native Entomopathogenic Nematodes and Parasitioids}

Entomopathogenic nematodes applied inundatively arrive into the soil together with vast numbers of competitors with which they are applied, and are also faced with an array of resident competitors including native EPN, parasitoids, or pathogens. During their evolutionary history, EPN typically emerge from hosts in groups, many of which are close relatives, and there is thus scope for cooperative behaviour to have been selected for.

\subsubsection{Aggregation: Cooperative Behaviour?}

Immediately after application, nematodes are expected to have a fairly uniform horizontal spatial distribution in soil (assuming a uniform application); however, with time this may tend towards the patchy or aggregated distribution more typical of natural populations (Campbell, Orza, Yoder, Lewis, \& Gaugler, 1998). A number of phenomena may contribute to this, including aggregation in preferred conditions (and extinction in more risky regions), or recycling through hosts resulting in patches of newly emerging IJs (Spiridonov, Moens, \& Wilson, 2007). Since natural soil is not uniform, interconnecting spaces may provide opportunity for IJs to be washed with irrigation or rain water into foci, or may form physically easier routes for IJs to traverse, resulting in aggregations. In addition to these processes, which do not require IJs to respond to each other, there is some evidence of aggregative behaviour, which does require animals to respond to each others' presence, in several species of EPN (El-Borai, Campos-Herrera, Stuart, \& Duncan, 2011; Shapiro-Ilan, Lewis, \& Schliekelman, 2014). This aggregative behaviour ("shoaling" or "herding") was exhibited both by IJs applied to sand in aqueous suspension as well as those emerging naturally from cadavers (El-Borai et al.; Shapiro-Ilan et al.). It is unclear to what extent this shoaling simply results from physical forces acting on the IJs, or involves integration by the nervous system. Little is known of the mechanism of collective movement in nematodes (Gart, Vella, \& Jung, 2011; Yuan, Raizen, \& Bau, 2014). Studying the movement of Panagrellus redivivus Goodey (Rhabditida: Panagrolaimidae), Gart et al. showed that nematodes in a thin layer of fluid come into contact spontaneously. They suggest that the initial aggregation is driven by random collisions between nematodes and continued collective motion is due to an attractive force arising from the surface tension of the water film (Gart et al.). Other physical forces may also contribute to 
aggregation, and systems of self-propelled particles are known for their tendency to aggregate and display swarming behaviour (Yang, Marceau, \& Gompper, 2010). For example, hydrodynamic interactions contribute to synchronisation and attraction of sperm (Yang, Elgeti, \& Gompper, 2008). On the other hand, social behaviour in feeding Caenorhabditis elegans Maupas (Rhabditida. Rhabditidae) is clearly under neural control (Boender, Roubos, \& van der Velde, 2011; Rogers, Persson, Cheung, \& de Bono, 2006). The mechanism involved in EPN aggregation is as yet unclear. However, even if it results from physical forces and is not a product of natural selection, aggregation may nevertheless be beneficial to the IJs. For example, there may be a requirement for a critical mass of IJs in order to kill certain insects (Peters \& Ehlers, 1994), and aggregation provides protection against natural enemies through dilution and shielding effects (Hamilton, 1971). Under desiccating conditions, IJs in a mass survive much better than isolated individuals, by providing a smaller surface area over which water is lost (O'Leary, Power, Stack, \& Burnell, 2001). However, there are also disadvantages to migrating in a group, including competition for host resources and inbreeding (Downes \& Griffin, 1996).

\subsubsection{Competition}

Infective juveniles that survive and infect an insect are not necessarily assured of reproductive success. Firstly, a lone Steinernema individual may kill a host (thereby satisfying the requirement of the biocontrol practitioner) but, being amphimictic, cannot reproduce. However, lone male and female $S$. feltiae survived up to 6 weeks within killed wax moth larvae (Rolston, Griffin, \& Downes, 2006), which may give them a chance of future mating opportunities. Secondly, they will compete with each other: overcrowding results in lower reproductive output per invading nematode (Koppenhöfer \& Kaya, 1995; Ryder \& Griffin, 2002; Selvan, Campbell, \& Gaugler, 1993; Zervos, Johnson, \& Webster, 1991). Above a certain inoculum level there is also a reduced output from the host, therefore lower recycling potential in the environment. For example, wax moth larvae inoculated with $500 \mathrm{H}$. bacteriophora produced no IJs (Zervos et al.), presumably due to overcrowding. The highest yield per host was obtained with an inoculum of $100 \mathrm{IJs}$, though the optimum inoculum level for the nematodes (yield per IJ of inoculum, rather than per host) was much lower (Zervos et al.). Thus, patterns of host invasion and utilisation that favour EPN population survival may conflict with those that maximise fitness of the individual IJ. As well as competing for host resources with each other, inundatively applied nematodes also compete with endemic pathogens (as discussed in Sect. 3.3) and parasites including native EPN and parasitoids.

Several studies have investigated the outcome of co-infections by two species of EPN in the laboratory. Laboratory studies found that Steinernema and Heterorhabditis could not co-exist in the same insect; Steinernema excluded Heterorhabditis, even if they infected up to $6 \mathrm{~h}$ later, probably due to bacteria-mediated interference competition (Alatorre-Rosas \& Kaya, 1990, 1991). However, in a recent study on 
native EPN populations, Galleria larvae used to bait field soils regularly contained progeny of both a Heterorhabditis and a Steinernema within the same cadaver (Campos-Herrera et al., 2015). Where two Steinernema species co-infect the one host individual, normally one species predominates in the emerging progeny (Bashey, Hawlena, \& Lively, 2012; Bashey, Reynolds, Sarin, \& Young, 2011; Kondo, 1989; Koppenhöfer, Kaya, Shanmugam, \& Wood, 1995; Půža \& Mráček 2009, 2010b; Sicard et al., 2006). Thus for example, S. feltiae produced scarcely any progeny in co-infections with either $S$. carpocapsae or $S$. glaseri (Kondo). Both exploitation and interference competition are implicated in the dominance of one Steinernema species over another, with the bacterial symbiont playing a role here also. Each species of Steinernema associates with a single species of Xenorhabdus, though one species of Xenorhabdus may associate with more than one Steinernema species (Adams et al., 2006). Although some species of Steinernema may feed on Xenorhabdus other than their natural associate, or even develop without symbiont, other Xenorhabdus less closely related to the natural associate may be detrimental to reproduction (Sicard et al., 2004; Sicard, Ramone, Le Brun, Pages, \& Moulia, 2005). Koppenhöfer et al. proposed that the superiority of $S$. glaseri over $S$. carpocapsae in co-infected hosts was due to both the faster development rate of $S$. glaseri and to its less specific relationship with its bacterial symbiont which allowed it to develop on the symbiont carried by its competitor. The relative numbers of bacteria carried by IJs of each species and the ability of the symbionts to produce bacteriocins (toxins that suppress other related strains of bacteria) (Bashey et al., 2012; Hawlena, Bashey, Mendes-Soares, \& Lively, 2010) may affect the outcome of the interaction between nematode species by favouring one symbiont over the other. Recently, a novel form of interference competition has been demonstrated in Steinernema, in which males physically injure and kill competitors, both male and female, of other Steinernema species (O'Callaghan, Zenner, Hartley, \& Griffin, 2014; Zenner, O'Callaghan, \& Griffin, 2014). A male wraps its tail end around the body of its competitor and squeezes, with the spicule pointing to the victim (Fig. 3.3). This may result in almost immediate paralysis, followed by death (Zenner et al.). The means by which this is achieved are unclear, but physical injuries including ruptured cuticle and damaged internal organs have been seen (Zenner et al.).

These laboratory studies indicate what may happen when two species find themselves in the same host, but EPN applied at high density may also impact on native populations less directly, through scramble competition for available hosts. Impacts on native EPN at the population level have been detected in the field. An introduced exotic species, S. riobrave, suppressed native H. bacteriophora, but not $S$. carpocapsae in a North Carolina cornfield (Millar \& Barbercheck, 2001). Similarly, Duncan, Graham et al. (2003) detected suppression of native EPN following application of exotic $S$. riobrave in Florida citrus. Since native EPN in Florida citrus are involved in regulating the target pest, $D$. abbreviatus citrus root weevil, suppression of these native EPN in plots treated with $S$. riobrave, combined with inferior persistence by the introduced species, reduced the net efficacy of $S$. riobrave against the weevils (Duncan, Graham et al.). While there may be a risk of competitive displacement of native EPN on a temporary basis, an international 


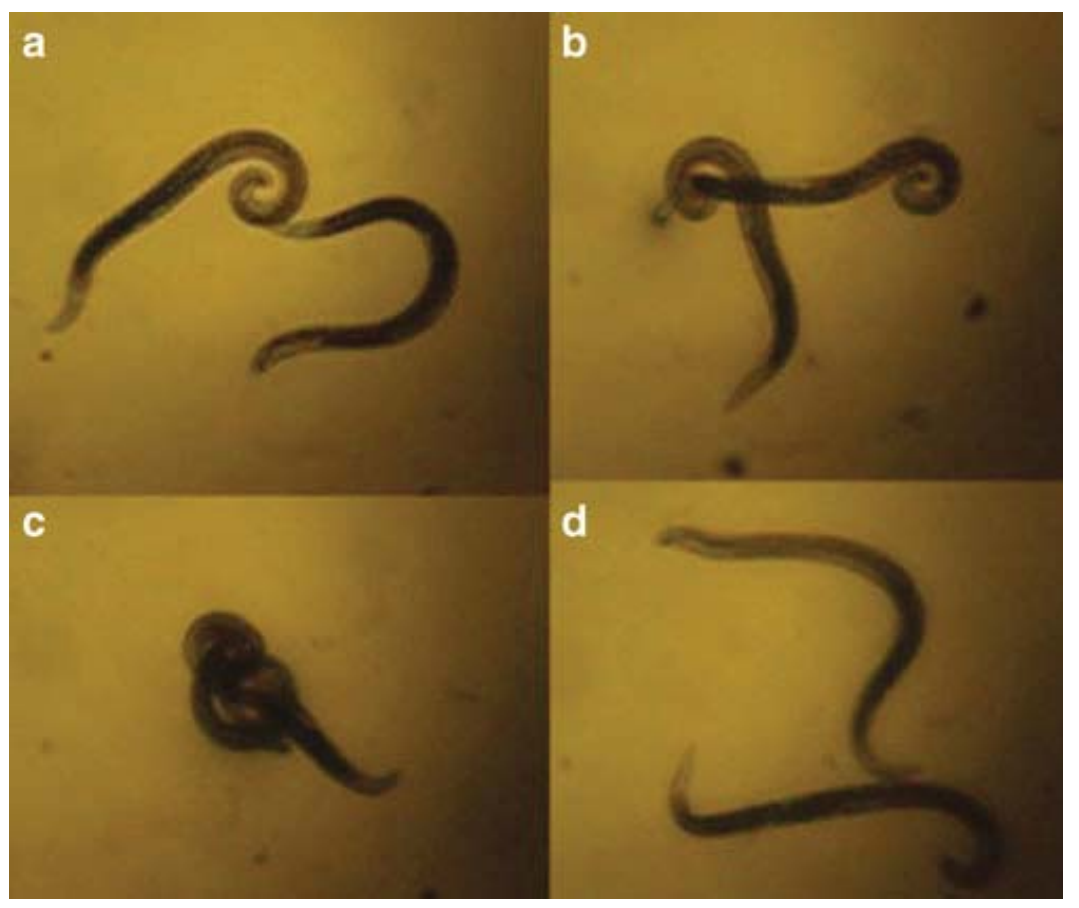

Fig. 3.3 Competition for resources (hosts and mates) may be intense in populations of entomopathogenic nematodes. Here, two Steinernema males fight in a drop of haemolymph. (a) One male wraps its tail around the other male's head; (b, c) the grip tightens; (d) the victim (lower male in the image) is immobilised within minutes of the encounter

panel of experts considered that there was no risk of permanent displacement (Ehlers \& Hokkanen, 1996). Even if there is short-term extinction at an application site, the native population may be re-established from neighbouring areas (Ram, Preisser, Gruner, \& Strong, 2008). Where the same species is both applied and indigenous, there is the possibility of hybridisation between the two, if co-infection of hosts occurs. Evidence of introgression was found for S. feltiae applied to tree stumps harbouring H. abietis pine weevils (Dillon, Rolston, et al., 2008). Genomewide molecular analysis (Amplified Fragment Length Polymorphism, AFLP) of $S$. feltiae isolates recovered 4 years later suggested possible hybridisation between the persisting and locally colonising strains (Dillon, Rolston et al.).

Top down control can be strengthened where natural enemies complement each other, or dampened by negative interactions (Letourneau, Jedlicka, Bothwell, \& Moreno, 2009). Parasitoids are widely introduced as biological control agents, and natural populations may exert considerable mortality of pest populations (Hawkins, Cornell, \& Hochberg, 1997), therefore interactions between EPN and parasitoids are of concern. EPN compete with parasitoids for hosts or attack and kill susceptible stages of parasitoid, an example of intraguild predation (Rosenheim, Kaya, Ehler, Marois, \& Jaffee, 1995). Ectoparasitoids are susceptible to nematode infection throughout larval development, but frequently become inaccessible at cocoon stage (Everard, Griffin, \& Dillon, 2009; Lacey, Unruh, \& Headrick, 2003), while endoparasitoids are susceptible for a shorter period, between emerging from the host and completing the cocoon (Kaya, 1978; Kaya \& Hotchkin, 1981; Shannag \& 
Capinera, 2000). In addition, parasitoid death due to premature nematode-induced host death has been reported in several laboratory studies. This is particularly clear in cases where the parasitoid itself is not infected by the nematodes (Head, Palmer, \& Walters, 2003; Kaya, 1978; Mráček \& Spitzer, 1983). In addition to killing individual parasitoids, nematodes might negatively impact on parasitoid populations if the female parasitoid lays her eggs on nematode-infected weevils where they are unable to complete their development. However, female parasitoids tend to avoid hosts that have been infected by EPN (Everard et al., 2009; Harvey \& Griffin, 2012; Lacey et al., 2003; Sher, Parrella, \& Kaya, 2000). Females of two ichneumonid species detected and avoided codling moth larvae as little as $12 \mathrm{~h}$ after treatment of the host with IJs (Lacey et al.). Such avoidance of oviposition on insect hosts infected with EPN is adaptive for the parasitoid and enhances the complementary effect of EPN for pest suppression (Lacey et al.), since parasitoids may "mop up" weevils that are not hit by nematodes.

Despite the negative effects of EPN on parasitoids demonstrated in the laboratory, the two types of agent may be compatible in the field, resulting in additive or even synergistic effects (Dillon, Moore, Downes, \& Griffin, 2008; Mbata \& ShapiroIlan, 2010). A critical feature is the timing of EPN application relative to peak times of susceptible parasitoid stages. In a field test of EPN against Cephalcia arvensis Panzer (Hymenoptera: Pamphiliidae) in Italy, one species of ichneumonid parasitoid was negatively impacted by EPN, while another was not (Battisti, 1994); it was suggested that the difference between species was due to the fact that most of the individuals of the unaffected species were diapausing within cocoons at the time of nematode application.

Free-living bactivorous nematodes (FLBN) may also colonise insect cadavers and represent another class of competitor (Duncan, Graham, et al., 2003; Duncan, Dunn, Bague, \& Nguyen, 2003). These nematodes such as Pellioditis were unable to kill insects themselves, but opportunistically invade EPN - killed cadavers and may significantly reduce the number of emerging IJs and hence the recycling capacity of applied nematodes (Duncan, Dunn et al.). If populations of FLBN increase in response to EPN density as suggested by field data (Campos-Herrera, El-Borai, \& Duncan, 2012; Somasekhar et al., 2002), FLBN may be a potential regulator of EPN populations (Duncan, Dunn et al.).

\subsection{Persistence and Spread of Populations}

Application of EPN is not generally aimed at long-term establishment (see Chap. 6). However, release of a large number of propagules may result in establishment and persistence of a population. Several factors conducive to persistence of EPN populations have already been identified, including stability of the ecosystem, availability of suitable hosts and heterogeneity in the nematode population in terms of survival potential and infectivity. The period during which hosts must be available will vary depending on the survival characteristics of the EPN population - the 
longer the IJs can survive, the shorter the period during which hosts must be present. To establish, the applied population must either be adapted to local climatic and edaphic conditions, or be capable of sufficiently rapid adaptation. Indeed, recent studies suggest that the success of a species in establishing in a new environment may depend more heavily on its ability to respond to natural selection than on having broad physiological tolerance (Lee, 2002; Prentis, Wilson, Dormontt, Richardson, \& Lowe, 2008). Both Heterorhabditis and Steinernema species have responded to artificial selection (e.g. Ehlers et al., 2005; Gaugler \& Campbell, 1991) and the short lifecycle of EPN means that adaptation may be rapid. Traditional views of ecological communities assume that they are full or saturated with species, but this may be less general than was previously thought, and even species-rich communities can still accept new-comers, resulting in increased species diversity (Sax et al., 2007). Thus, given time, applied EPN may establish even if not well adapted to local conditions, and despite competition.

Whether or not the site at which EPN are inundatively applied is suitable for long-term establishment of a population, it may provide a jumping off point or beach-head for colonisation of a more suitable habitat. This is of particular interest where using a nematode species that is not native in the region of its use. While active dispersal by nematodes results in local displacement in the order of centimetres, passive dispersal by wind, water or animals may result in translocation to greater distances. Phoresis or other external contamination of animals is the most widely considered explanation for rapid short-range dispersal (Jabbour \& Barbercheck, 2008) or long-range dispersal over several hundred meters or kilometres (Barratt, Blossey, \& Hokkanen, 2006). Several types of soil invertebrates have potential to act as phoretic hosts for EPN, including earthworms (Campos-Herrera, Trigo, \& Gutierrez, 2006; Shapiro, Tylka, Berry, \& Lewis, 1995), isopods (Eng, Preisser, \& Strong, 2005), predatory carabid beetles (Mertz, Agudelo, Sales, Rohde, \& Moino, 2014) and termites (Zadji, Baimey, Afouda, Moens, \& Decraemer, 2014). However, only insects capable of flight will result in significant displacement of EPN from the site of application. Lacey, Kaya, and Bettencourt (1995) showed that Japanese beetles $P$. japonica infected in the laboratory were capable of dispersing EPN by flight for at least $50 \mathrm{~m}$, either in their haemocoel or externally. Many of the infected beetles contained enough nematodes to allow reproduction (Lacey et al.). Similarly, infected adult beet armyworm Spodoptera exigua Hubner (Lepidoptera: Noctuidae) transported EPN up to $11 \mathrm{~m}$ and nematode progeny from the dead moths moved into the soil where they infected larvae of the same species (Timper, Kaya, \& Gaugler, 1988). Adult pine weevil H. abietis, which are capable of flight, transported EPN on their elytra (Kruitbos, Heritage, \& Wilson, 2009). Since they are also susceptible to EPN infection and survive for several days post-infection (Girling, Ennis, Dillon, \& Griffin, 2010), internal transport in these weevils is also possible. Following application of S. scapterisci to control mole crickets, infected insects were collected as far as $23 \mathrm{~km}$ from the nearest site of application, and this method of dissemination was important in establishing the species as part of a strategy of mole cricket suppression in Florida (Parkman \& Smart, 1996). Strong et al. (1996) suggest that dispersal of EPN may occur when moist soil particles 
adhere to fossorial insects and mammals. Dispersal by larger animals including unintentional dispersal by humans is also possible. Human assisted movement of plant parasitic nematodes in soil associated with machinery, vehicles and human footwear as well as in growing media accompanying plants is well documented (reviewed by Singh, Hodda, Ash, and Banks 2013). As well as effecting local dispersal, humans can also be responsible for global dispersal of nematodes. For example, live EPN, both Heterorhabditis and Steinernema were recovered from soil on footwear from aircraft passengers' baggage (McNeill et al., 2011).

It is likely that EPN can be dispersed by wind and water also. In a theoretical analysis, Carroll and Viglierchio (1981) considered that wind transport of nematode juveniles up to $5 \mathrm{~km}$ should be fairly common, with rarer redeposition events up to $40 \mathrm{~km}$ from their original location. Wind dissemination of nematodes, including bacterial feeders has been experimentally demonstrated in arid regions including sub-saharan Africa and Antarctica (Baujard \& Martiny, 1994; Nkem et al., 2006). According to Nkem et al. the ability to enter anhydrobiosis may be important for wind transport over longer distances, as dry organisms, being lighter, will be carried further (Nathan et al., 2002) and will also survive dry conditions during transport. Although EPN are not capable of true anhydrobiosis they can enter a state of quiescent anhydrobiosis in response to slow drying (Grewal, Bornstein-Forst, Burnell, Glazer, \& Jagdale, 2006). Runoff water was shown to be an important transport mechanism for plant parasites at the field level (Chabrier \& Queneherve, 2008), while in coastal environments, transport in sea water is an additional possibility (de la Peña, Vandegehuchte, Bonte, \& Moens, 2011). Sand dunes are subject to periodic erosion and redeposition by storms (Pye, 1983), providing ample opportunity for redistribution of organisms. Short distance dispersal trapped in mucilaginous foam at the surface (Thornton, 1999) or longer distance dispersal in vegetation rafts (Fuller, Schwarz, \& Tierney, 2005) are theoretically possible. IJs of three Heterorhabditis species survived prolonged immersion in sea water, and remained infective for 19 weeks, making this a plausible means of dispersal for EPN in coastal locations (Griffin, Finnegan, \& Downes, 1994).

Since nematodes at or near the surface are more likely to be picked up by wind (Nkem et al., 2006) and transported by surface water and soil erosion events (Baxter, Rowan, McKenzie, \& Neilson, 2013), EPN species that adopt an ambush foraging strategy may be more susceptible to long-distance transport by these means. In line with its surface location, $S$. carpocapsae is generally the most desiccation tolerant species of EPN (Shapiro-Ilan, Brown, \& Lewis, 2014), an advantage in wind dispersal. EPN at the soil surface are also more likely to be transported by phoresis. Indeed, the nictation and jumping behaviours that are primarily seen as adaptations to host-finding (Campbell \& Kaya, 1999, 2002) may also serve to attach to phoretic hosts (either susceptible or not) resulting in displacement of the nematodes. Dauer juveniles of free-living nematodes such as $C$. elegans also nictate, and for this species nictation primarily serves as a dispersal behaviour (Lee et al., 2012). Nictation may have played a part in the evolution of parasitism from free-living nematodes through necromeny to entomopathogeny (Brown, D'Anna, \& Sommer, 2011; Sudhaus, 2008). 
While the means by which EPN might disperse can be identified, the extent to which dispersal takes place can best be addressed by molecular population studies, as has been done for other nematodes (e.g. Andersen et al., 2012; Morgan, McGaughran, Ganeshan, Herrmann, \& Sommer, 2014). Limited studies that have been done to date with EPN show no correlation between genetic similarity of populations and their geographical proximity, indicating a high level of gene flow (Rolston, Meade, Boyle, Kakouli-Duarte, \& Downes, 2009; Wang et al., 2013) and suggesting that long-distance dispersal events of the kind discussed here are relatively common.

Little is known of establishment probabilities of nematodes following dispersal events (McNeill et al., 2011). As for establishment at the site where EPN are applied, establishment following dispersal from such sites will depend on adequate numbers of individuals, their adaptation to local conditions, and the range of available hosts and competitors (Giblin-Davis, Kanzaki, \& Davies, 2013; Singh et al., 2013). Hermaphroditic species such as Heterorhabditis and S. hermaphroditum have an advantage, as each IJ is a potential colonist. Dispersal has important consequences for gene flow, the local and global persistence of species, and the evolution of lifehistory traits (de la Peña et al., 2011; Ronce, 2007). While even rare dispersal events may allow an applied EPN to establish outside the area of its application, or gradually extend the range of a species, frequent local dispersal events may also facilitate long-term persistence of a species (Simberloff, 2009). Dispersal affects the distribution of genetic diversity contained within populations, and can help mitigate the effect of genetic drift in small populations, decrease mutation load and thereby reduce the risk of extinction (Ronce).

Much can be learnt about factors influencing longer term persistence of applied EPN from natural systems. Natural populations persist for years, and the patchy nature of the distribution within and between sites is consistent with the metapopulation concept (Stuart et al., 2006). An endemic population of $H$. marelatus persisted at high incidence at some but not all sites at Bodega Bay, California, and factors affecting the probability of persistence included local variation in abiotic conditions and metapopulation dynamics (Ram, Gruner, McLaughlin, Preisser, \& Strong, 2008; Ram, Preisser, et al., 2008). Over a 13 year study period, colonization rates were highly correlated with long-term persistence. Sites with highest long-term persistence experienced the highest rate of colonization, extinction and turnover, leading to the conclusion that $H$. marelatus at Bodega Bay is a dynamic metapopulation (Ram, Preisser et al.).

\subsection{Conclusions and Future Directions}

EPN have been shaped by millions of years of evolution; like the early wild grasses from which cereals were bred, EPN behavioural and survival strategies may be far from ideal from the human perspective. Studies on their behaviour are broadening beyond foraging strategies and responses to insects reviewed by 
Lewis et al. (2006). For example, the demonstration by Rasmann et al. (2005) that EPN respond to herbivore-induced plant volatiles spurred further research in this area, while the recent documentation of a large class of ascaroside signalling molecules in nematodes including EPN opens further exciting horizons (Choe et al., 2012; Kaplan et al., 2012). Research aimed toward the practical goal of genetic improvement of EPN (see Chap. 2) is providing insights into the genetic basis of important traits related to survival and infectivity, while exciting comparative studies encompassing EPN along with other parasites and the intensively studied C. elegans holds prospects for understanding both the mechanisms and evolution of behaviours including dispersal and host finding (Hallem et al., 2011; Kaplan et al.).

Although applied in their miles of millons, it is important to remember that IJs are individuals, each of which is attempting to achieve the best reproductive opportunities it can. Even in inbred domesticated strains produced under standardised conditions, not all individuals are the same; genetic variation and the varied conditions experienced by IJs from fermenter to soil will result in physiological and behavioural diversity. The importance of heterogeneity for long-term persistence of the population has been noted. Exploring individual differences in traits like infectivity or host finding is more difficult than for survival, and unravelling the causes of heterogeneity is challenging, especially when each individual is changing over time.

While continued presence of applied EPN may be desirable for sustained suppression of pest populations, establishment and persistence of populations, especially of exotic nematodes, is of environmental concern. Molecular ecology techniques have potential for studying population events including dispersal, introgression, and genetic adaptation, but have not been widely applied. Studies at local level of recent events following inundative application could also contribute to understanding EPN biogeography, since the current natural distribution is a product of earlier dispersal events, some of which might be quite recent.

The diversity of EPN species and experimental questions addressed can sometimes make it difficult to discern patterns from amongst the data. In depth multi-year programmes of interlinked field and laboratory studies, are important in understanding the behaviour and fate of EPN individuals and populations, whether natural (Strong, 2002) or applied (see Chap. 13).

\section{References}

Abu Hatab, M., Gaugler, R., \& Ehlers, R. U. (1998). Influence of culture method on Steinernema glaseri lipids. Journal of Parasitology, 84, 215-221.

Abu Hatab, M. A., \& Gaugler, R. (1999). Lipids of in vivo and in vitro cultured Heterorhabditis bacteriophora. Biological Control, 15, 113-118.

Acevedo, J. P. M., Samuels, R. I., Machado, I. R., \& Dolinski, C. (2007). Interactions between isolates of the entomopathogenic fungus Metarhizium anisopliae and the entomopathogenic nematode Heterorhabditis bacteriophora JPM4 during infection of the sugar cane borer Diatraea saccharalis (Lepidoptera: Pyralidae). Journal of Invertebrate Pathology, 96, 187-192. 
Adams, B. J., Fodor, A., Koppenhöfer, H. S., Stackebrandt, E., Stock, S. P., \& Klein, M. G. (2006). Biodiversity and systematics of nematode-bacterium entomopathogens. Biological Control, 37, 32-49.

Alatorre-Rosas, R., \& Kaya, H. K. (1990). Interspecific competition between entomopathogenic nematodes in the genera Heterorhabditis and Steinernema for an insect host in sand. Journal of Invertebrate Pathology, 55, 179-188.

Alatorre-Rosas, R., \& Kaya, H. K. (1991). Interaction between two entomopathogenic nematode species in the same host. Journal of Invertebrate Pathology, 57, 1-6.

Ali, J. G., Alborn, H. T., \& Stelinski, L. L. (2011). Constitutive and induced subterranean plant volatiles attract both entomopathogenic and plant parasitic nematodes. Journal of Ecology, 99, 26-35.

Ali, J. G., Campos-Herrera, R., Alborn, H. T., Duncan, L. W., \& Stelinski, L. L. (2013). Sending mixed messages: A trophic cascade produced by a belowground herbivore-induced cue. Journal of Chemical Ecology, 39, 1140-1147.

Anbesse, S. A., Adge, B. J., \& Gebru, W. M. (2008). Laboratory screening for virulent entomopathogenic nematodes (Heterorhabditis bacteriophora and Steinernema yirgalemense) and fungi (Metarhizium anisophae and Beauveria bassiana) and assessment of possible synergistic effects of combined use against grubs of the barley chafer Coptognathus curtipennis. Nematology, 10, 701-709.

Andalo, V., Moino, A., Maximiniano, C., Campos, V. P., \& Mendonca, L. A. (2011). Influence of temperature and duration of storage on the lipid reserves of entomopathogenic nematodes. Revista Colombiana De Entomologia, 37, 203-209.

Andersen, E. C., Gerke, J. P., Shapiro, J. A., Crissman, J. R., Ghosh, R., Bloom, J. S., et al. (2012). Chromosome-scale selective sweeps shape Caenorhabditis elegans genomic diversity. Nature Genetics, 44, 285-290.

Ansari, M. A., \& Butt, T. M. (2011). Effect of potting media on the efficacy and dispersal of entomopathogenic nematodes for the control of black vine weevil, Otiorhynchus sulcatus (Coleoptera: Curculionidae). Biological Control, 58, 310-318.

Ansari, M. A., Shah, F. A., \& Butt, T. M. (2008). Combined use of entomopathogenic nematodes and Metarhizium anisopliae as a new approach for black vine weevil, Otiorhynchus sulcatus, control. Entomologia Experimentalis et Applicata, 129, 340-347.

Atwa, A. A., Hegazi, E. M., Khafagi, W. E., \& Abd El-Aziz, G. M. (2013). Interaction of the koinobiont parasitoid Microplitis rufiventris of the cotton leafworm, Spodoptera littoralis, with two entomopathogenic rhabditids, Heterorhabditis bacteriophora and Steinernema carpocapsae. Journal of Insect Science, 13, 84.

Bal, H. K., Taylor, R. A. J., \& Grewal, P. S. (2014). Ambush foraging entomopathogenic nematodes employ 'sprinting emigrants' for long distance dispersal in the absence of hosts. Journal of Nematology, 44, 450-451.

Barbercheck, M. E., \& Kaya, H. K. (1990). Interactions between Beauveria bassiana and the entomogenous nematodes, Steinernema feltiae and Heterorhabditis heliothidis. Journal of Invertebrate Pathology, 55, 225-234.

Barbercheck, M. E., \& Kaya, H. K. (1991). Competitive interactions between entomopathogenic nematodes and Beauveria bassiana (Deuteromycotina: Hyphomycetes) in soilborne larvae of Spodotera exigua (Lepidoptera: Noctuidae). Environmental Entomology, 20, 707-712.

Barbercheck, M. E., Wang, J., \& Hirsh, I. S. (1995). Host plant effects on entomopathogenic nematodes. Journal of Invertebrate Pathology, 66, 169-177.

Barratt, B. I. P., Blossey, B., \& Hokkanen, H. M. T. (2006). Post-release evaluation of nontarget effects of biological control agents. In F. Bigler, D. Babendreier, \& U. Kuhlmann (Eds.), Environmental impact of invertebrates for biological control of arthropods: Methods and risk assessment (pp. 166-186). Wallingford, UK: CABI.

Bashey, F., Hawlena, H., \& Lively, C. M. (2012). Alternative paths to success in a parasite community: Within-host competition can favor higher virulence or direct interference. Evolution, 67, 900-907. 
Bashey, F., Reynolds, C., Sarin, T., \& Young, S. K. (2011). Virulence and competitive ability in an obligately killing parasite. Oikos, 120, 1539-1545.

Battisti, A. (1994). Effects of entomopathogenic nematodes on the spruce web-spinning sawfly Cephalcia arvensis Panzer and its parasitoids in the field. Biocontrol Science and Technology, 4, 95-102.

Baujard, P., \& Martiny, B. (1994). Transport of nematodes by wind in the peanut cropping area of Senegal, West-Africa. Fundamental and Applied Nematology, 17, 543-550.

Baxter, C., Rowan, J. S., McKenzie, B. M., \& Neilson, R. (2013). Understanding soil erosion impacts in temperate agroecosystems: Bridging the gap between geomorphology and soil ecology using nematodes as a model organism. Biogeosciences, 10, 7133-7145.

Bird, A. F., \& Bird, J. (1986). Observations on the use of insect parasitic nematodes as a means of biological control of root-knot nematodes. International Journal for Parasitology, 16, 511-516.

Boender, A. J., Roubos, E. W., \& van der Velde, G. (2011). Together or alone? Foraging strategies in Caenorhabditis elegans. Biological Reviews, 86, 853-862.

Boff, M. I. C., van Tol, R., \& Smits, P. H. (2002). Behavioural response of Heterorhabditis megidis towards plant roots and insect larvae. Biocontrol, 47, 67-83.

Boff, M. I. C., Zoon, F. C., \& Smits, P. H. (2001). Orientation of Heterorhabditis megidis to insect hosts and plant roots in a Y-tube sand olfactometer. Entomologia Experimentalis et Applicata, 98, 329-337.

Bohan, D. A., \& Hominick, W. M. (1996). Investigations on the presence of an infectious proportion amongst populations of Steinernema feltiae (Site 76 strain) infective stages. Parasitology, 112, 113-118.

Bohan, D. A., \& Hominick, W. M. (1997). Long term dynamics of infectiousness within the infective stage pool of the entomopathogenic nematode Steinernema feltiae (Site 76 strain) Filipjev. Parasitology, 114, 301-308.

Bolnick, D. I., Svanback, R., Fordyce, J. A., Yang, L. H., Davis, J. M., Hulsey, C. D., et al. (2003). The ecology of individuals: Incidence and implications of individual specialization. American Naturalist, 161, 1-28.

Brown, F. D., D’Anna, I., \& Sommer, R. J. (2011). Host-finding behaviour in the nematode Pristionchus pacificus. Proceedings of the Royal Society B-Biological Sciences, 278, 3260-3269.

Brown, I. M., \& Gaugler, R. (1996). Cold tolerance of steinernematid and heterorhabitid nematodes. Journal of Thermal Biology, 21, 115-121.

Burman, M., \& Pye, A. E. (1980). Neoaplectana carpocapsae - movements of nematode populations on a thermal gradient. Experimental Parasitology, 49, 258-265.

Burr, A. H. J., \& Robinson, A. F. (2004). Locomotion behaviour. In R. Gaugler \& A. L. Bilgrami (Eds.), Nematode behaviour (pp. 25-62). Wallingford, UK: CABI.

Byers, J. A., \& Poinar, G. O. (1982). Location of insect hosts by the nematode Neoaplectana carpocapsae, in response to temperature. Behaviour, 79, 1-10.

Campbell, J., \& Gaugler, R. (1993). Nictation behaviour and its ecological implications in the host search strategies of entomopathogenic nematodes (Heterorhabditidae and Steinernematidae). Behaviour, 126, 154-169.

Campbell, J. F., \& Gaugler, R. (1997). Inter-specific variation in entomopathogenic nematode. Foraging strategy: Dichotomy or variation along a continuum? Fundamental and Applied Nematology, 20, 393-398.

Campbell, J. F., \& Kaya, H. K. (1999). How and why a parasitic nematode jumps. Nature, 397, 485-486.

Campbell, J. F., \& Kaya, H. K. (2002). Variation in entomopathogenic nematode (Steinernematidae and Heterorhabditidae) infective-stage jumping behaviour. Nematology, 4, 471-482.

Campbell, J. F., \& Lewis, E. E. (2002). Entomopathogenic nematode host-search strategy. In E. E. Lewis, J. F. Campbell, \& M. V. K. Sukhdeo (Eds.), The behavioural ecology of parasites (pp. 13-38). Wallingford, UK: CABI.

Campbell, J. F., Lewis, E. E., Stock, S. P., Nadler, S., \& Kaya, H. K. (2003). Evolution of host search strategies in entomopathogenic nematodes. Journal of Nematology, 35, 142-145. 
Campbell, J. F., Orza, G., Yoder, F., Lewis, E., \& Gaugler, R. (1998). Spatial and temporal distribution of endemic and released entomopathogenic nematode populations in turfgrass. Entomologia Experimentalis et Applicata, 86, 1-11.

Campos-Herrera, R., Barbercheck, M., Hoy, C. W., \& Stock, S. P. (2012). Entomopathogenic nematodes as a model system for advancing the frontiers of ecology. Journal of Nematology, $44,162-176$.

Campos-Herrera, R., El-Borai, F. E., \& Duncan, L. W. (2012). Wide interguild relationships among entomopathogenic and free-living nematodes in soil as measured by real time qPCR. Journal of Invertebrate Pathology, 111, 126-135.

Campos-Herrera, R., Jaffuel, G., Chiriboga, X., Blanco-Perez, R., Fesselet, M., Půža, V., et al. (2015). Traditional and molecular detection methods reveal intense interguild competition and other multitrophic interactions associated with native entomopathogenic nematodes in Swiss tillage soils. Plant and Soil, 389, 237-255.

Campos-Herrera, R., Pathak, E., El-Borai, F. E., Schumann, A., Abd-Elgawad, M. M. M., \& Duncan, L. W. (2013). New citriculture system suppresses native and augmented entomopathogenic nematodes. Biological Control, 66, 183-194.

Campos-Herrera, R., Trigo, D., \& Gutierrez, C. (2006). Phoresy of the entomopathogenic nematode Steinernema feltiae by the earthworm Eisenia fetida. Journal of Invertebrate Pathology, 92, 50-54.

Carminati, A., Schneider, C. L., Moradi, A. B., Zarebanadkouki, M., Vetterlein, D., Vogel, H. J., et al. (2011). How the rhizosphere may favor water availability to roots. Vadose Zone Journal, 10, 988-998.

Carroll, J. J., \& Viglierchio, D. R. (1981). On the transport of nematodes by the wind. Journal of Nematology, 13, 476-483.

Chabrier, C., \& Queneherve, P. (2008). Preventing nematodes from spreading: A case study with Radopholus similis (Cobb) Thorne in a banana field. Crop Protection, 27, 1237-1243.

Chiriboga, X., Jaffuel, G., Campos-Herrera, R., Roëder, G., \& Turlings, T. C. J. (2014, August 17-22). (E)-b-Caryophyllene diffuses differently regarding soil texture type. 15 th International Symposium on Insect-Plant Relationships, University of Neuchâtel, Switzerland.

Choe, A., von Reuss, S. H., Kogan, D., Gasser, R. B., Platzer, E. G., Schroeder, F. C., et al. (2012). Ascaroside signaling is widely conserved among nematodes. Current Biology, 22, 772-780.

Choo, H. Y., \& Kaya, H. K. (1991). Influence of soil texture and presence of roots on host finding by Heterorhabditis bacteriophora. Journal of Invertebrate Pathology, 58, 279-280.

Choo, H. Y., Kaya, H. K., Burlando, T. M., \& Gaugler, R. (1989). Entomopathogenic nematodes: Host-finding ability in the presence of plant roots. Environmental Entomology, 18, 1136-1140.

Christen, J. M., Campbell, J. F., Lewis, E. E., Shapiro-Ilan, D. I., \& Ramaswamy, S. B. (2007). Responses of the entomopathogenic nematode, Steinernema riobrave to its insect hosts, Galleria mellonella and Tenebrio molitor. Parasitology, 134, 889-898.

Combes, C. (1991). Evolution of parasite life cycles. In C. A. Tofts, A. Aeschlimann, \& C. Bolis (Eds.), Parasite host associations: Coexistence or conflict? (pp. 63-82). Oxford, UK: Oxford University Press.

Cutler, C. G., \& Webster, J. M. (2003). Host-finding ability of three entomopathogenic nematode isolates in the presence of plant roots. Nematology, 5, 601-608.

de Altube, M. D. M., Strauch, O., de Castro, G. F., \& Pena, A. M. (2008). Control of the flat-headed root borer Capnodis tenebrionis (Linne) (Coleoptera: Buprestidae) with the entomopathogenic nematode Steinernema carpocapsae (Weiser) (Nematoda: Steinernematidae) in a chitosan formulation in apricot orchards. BioControl, 53, 531-539.

de la Peña, E., Vandegehuchte, M. L., Bonte, D., \& Moens, M. (2011). Nematodes surfing the waves: Long-distance dispersal of soil-borne microfauna via sea swept rhizomes. Oikos, 120, 1649-1656.

Demarta, L., Hibbard, B. E., Bohn, M. O., \& Hiltpold, I. (2014). The role of root architecture in foraging behavior of entomopathogenic nematodes. Journal of Invertebrate Pathology, 122 , 32-39. 
Dembilio, O., Llacer, E., de Altube, M. D. M., \& Jacas, J. A. (2010). Field efficacy of imidacloprid and Steinernema carpocapsae in a chitosan formulation against the red palm weevil Rhynchophorus ferrugineus (Coleoptera: Curculionidae) in Phoenix canariensis. Pest Management Science, 66, 365-370.

Dempsey, C. M., \& Griffin, C. T. (2002). Phased activity in Heterorhabditis megidis. Parasitology, $124,605-613$.

Dillman, A. R., Guillermin, M. L., Lee, J. H., Kim, B., Sternberg, P. W., \& Hallem, E. A. (2012). Olfaction shapes host-parasite interactions in parasitic nematodes. Proceedings of the National Academy of Sciences of the United States of America, 109, E2324-E2333.

Dillon, A. B., Moore, C. P., Downes, M. J., \& Griffin, C. T. (2008). Evict or infect? Managing populations of the large pine weevil, Hylobius abietis, using a bottom-up and top-down approach. Forest Ecology and Management, 255, 2634-2642.

Dillon, A. B., Rolston, A. N., Meade, C. V., Downes, M. J., \& Griffin, C. T. (2008). Establishment, persistence, and introgression of entomopathogenic nematodes in a forest ecosystem. Ecological Applications, 18, 735-747.

Dillon, A. B., Ward, D., Downes, M. J., \& Griffin, C. T. (2006). Suppression of the large pine weevil Hylobius abietis (L.) (Coleoptera: Curculionidae) in pine stumps by entomopathogenic nematodes with different foraging strategies. Biological Control, 38, 217-226.

Dini-Andreote, F., \& van Elsas, J. D. (2013). Back to the basics: The need for ecophysiological insights to enhance our understanding of microbial behaviour in the rhizosphere. Plant and Soil, 373, 1-15.

Downes, M. J., \& Griffin, C. T. (1996). Dispersal behaviour and transmission strategies of the entomopathogenic nematodes Heterorhabditis and Steinernema. Biocontrol Science and Technology, 6, 347-356.

Dugaw, C. J., \& Ram, K. (2011). Individual heterogeneity in mortality mediates long-term persistence of a seasonal microparasite. Oecologia, 166, 317-325.

Duncan, L., \& McCoy, C. (2001). Hydraulic lift increases herbivory by Diaprepes abbreviatus larvae and persistence of Steinernema riobrave in dry soil. Nematology, 33, 142-146.

Duncan, L. W., Dunn, D. C., Bague, G., \& Nguyen, K. (2003). Competition between entomopathogenic and free-living bactivorous nematodes in larvae of the weevil Diaprepes abbreviatus. Journal of Nematology, 35, 187-193.

Duncan, L. W., Graham, J. H., Dunn, D. C., Zellers, J., McCoy, C. W., \& Nguyen, K. (2003). Incidence of endemic entomopathogenic nematodes following application of Steinerema riobrave for control of Diaprepes abbreviatus. Journal of Nematology, 35, 178-186.

Duncan, L. W., Stuart, R. J., El-Borai, F. E., Campos-Herrera, R., Pathak, E., Giurcanu, M., et al. (2013). Modifying orchard planting sites conserves entomopathogenic nematodes, reduces weevil herbivory and increases citrus tree growth, survival and fruit yield. Biological Control, 64, 26-36.

Dusenbery, D. B. (1987). Theoretical range over which bacteria and nematodes locate plant roots using carbon dioxide. Journal of Chemical Ecology, 13, 1617-1624.

Dutky, S. R., Thompson, J. V., \& Cantwell, G. E. (1964). A technique for the mass propagation of the DD-136 nematode. Journal of Insect Pathology, 6, 417-422.

Ebssa, L., \& Koppenhöfer, A. M. (2011). Efficacy and persistence of entomopathogenic nematodes for black cutworm control in turfgrass. Biocontrol Science and Technology, 21, 779-796.

Ebssa, L., \& Koppenhöfer, A. M. (2012). Entomopathogenic nematodes for the management of Agrotis ipsilon: Effect of instar, nematode species and nematode production method. Pest Management Science, 68, 947-957.

Ehlers, R. U., \& Hokkanen, H. M. T. (1996). Insect biocontrol with non-endemic entomopathogenic nematodes (Steinernema and Heterorhabditis spp): Conclusions and recommendations of a combined OECD and COST Workshop on Scientific and Regulatory Policy Issues. Biocontrol Science and Technology, 6, 295-302.

Ehlers, R. U., Oestergaard, J., Hollmer, S., Wingen, M., \& Strauch, O. (2005). Genetic selection for heat tolerance and low temperature activity of the entomopathogenic nematode-bacterium complex Heterorhabditis bacteriophora-Photorhabdus luminescens. BioControl, 50, 699-716. 
El-Borai, F. E., Campos-Herrera, R., Stuart, R. J., \& Duncan, L. W. (2011). Substrate modulation, group effects and the behavioral responses of entomopathogenic nematodes to nematophagous fungi. Journal of Invertebrate Pathology, 106, 347-356.

Elmowitz, D. E., Ebssa, L., \& Koppenhöfer, A. M. (2014). Overwintering behavior of the entomopathogenic nematodes Steinernema scarabaei and Heterorhabditis bacteriophora and their white grub hosts. Entomologia Experimentalis et Applicata, 148, 246-258.

Eng, M. S., Preisser, E. L., \& Strong, D. R. (2005). Phoresy of the entomopathogenic nematode Heterorhabditis marelatus by a non-host organism, the isopod Porcellio scaber. Journal of Invertebrate Pathology, 88, 173-176.

Ennis, D. E., Dillon, A. B., \& Griffin, C. T. (2010). Simulated roots and host feeding enhance infection of subterranean insects by the entomopathogenic nematode Steinernema carpocapsae. Journal of Invertebrate Pathology, 103, 140-143.

Everard, A., Griffin, C. T., \& Dillon, A. B. (2009). Competition and intraguild predation between the braconid parasitoid Bracon hylobii and the entomopathogenic nematode Heterorhabditis downesi, natural enemies of the large pine weevil, Hylobius abietis. Bulletin of Entomological Research, 99, 151-161.

Fallon, D. J. (1998). The use of indigenous entomopathogenic nematodes (Heterorhabditis indica and Steinernema spp.) to control rice stem borer in West Java, Indonesia. Ph.D. Thesis, National University of Ireland, Maynooth.

Fenton, A., \& Hudson, P. J. (2002). Optimal infection strategies: Should macroparasites hedge their bets? Oikos, 96, 92-101.

Ferguson, C. S., Schroeder, P. C., \& Shields, E. J. (1995). Vertical distribution, persistence, and activity of entomopathogenic nematodes (Nematoda: Heterorhabditidae and Steinernematidae) in alfalfa snout beetle (Coleoptera: Curculionidae) infested fields. Environmental Entomology, 24, 149-158.

Fitters, P. F. L., \& Griffin, C. T. (2006). Survival, starvation, and activity in Heterorhabditis megidis (Nematoda: Heterorhabditidae). Biological Control, 37, 82-88.

Fitters, P. F. L., Patel, M. N., Griffin, C. T., \& Wright, D. J. (1999). Fatty acid composition of Heterorhabditis sp during storage. Comparative Biochemistry and Physiology B-Biochemistry \& Molecular Biology, 124, 81-88.

Fuller, S., Schwarz, M., \& Tierney, S. (2005). Phylogenetics of the allodapine bee genus Braunsapis: Historical biogeography and long-range dispersal over water. Journal of Biogeography, $32,2135-2144$.

Gart, S., Vella, D., \& Jung, S. (2011). The collective motion of nematodes in a thin liquid layer. Soft Matter, 7, 2444-2448.

Gaugler, R., \& Campbell, J. F. (1991). Selection for enhanced host-finding of scarab larvae (Coleoptera: Scarabaeidae) in an entomopathogenic nematode. Environmental Entomology, 20, 700-706.

Gaugler, R., \& Georgis, R. (1991). Culture method and efficacy of entomopathogenic nematodes (Rhabditida: Steinernematidae and Heterorhabditidae). Biological Control, 1, 269-274.

Gaugler, R., Lewis, E., \& Stuart, R. J. (1997). Ecology in the service of biological control: The case of entomopathogenic nematodes. Oecologia, 109, 483-489.

Georgis, R., \& Poinar, G. O. (1983). Effect of soil texture on the distribution and infectivity of Neoaplectana carpocapasae (Nematoda: Steinernematidae). Journal of Nematology, 15, 308311.

Giblin-Davis, R. M., Kanzaki, N., \& Davies, K. A. (2013). Nematodes that ride insects: Unforeseen consequences of arriving species. Florida Entomologist, 96, 770-780.

Girling, R. D., Ennis, D., Dillon, A. B., \& Griffin, C. T. (2010). The lethal and sub-lethal consequences of entomopathogenic nematode infestation and exposure for adult pine weevils, Hylobius abietis (Coleoptera: Curculionidae). Journal of Invertebrate Pathology, 104, 195-202.

Glazer, I. (1997). Effects of infected insects on secondary invasion of steinernematid entomopathogenic nematodes. Parasitology, 114, 597-604. 
Gouge, D. H., \& Hague, N. G. M. (1995). The development of Steinernema feltiae (Nematoda: Steinernematidae) in the sciarid fly Bradysia paupera (Diptera: Sciaridae). Annals of Applied Biology, 126, 395-401.

Grewal, P. S. (2002). Formulation and application technology. In R. Gaugler (Ed.), Entomopathogenic nematology (pp. 265-287). Wallingford, UK: CAB International.

Grewal, P. S., Bornstein-Forst, S., Burnell, A. M., Glazer, I., \& Jagdale, G. B. (2006). Physiological, genetic, and molecular mechanisms of chemoreception, thermobiosis, and anhydrobiosis in entomopathogenic nematodes. Biological Control, 38, 54-65.

Grewal, P. S., Converse, V., \& Georgis, R. (1999). Influence of production and bioassay methods on infectivity of two ambush foragers (Nematoda: Steinernematidae). Journal of Invertebrate Pathology, 73, 40-44.

Grewal, P. S., Gaugler, R., \& Lewis, E. E. (1993). Host recognition by entomopathogenic nematodes during contact with insect gut contents. Journal of Parasitology, 79, 495-503.

Grewal, P. S., Gaugler, R., \& Selvan, S. (1993). Host recognition by entomopathogenic nematodes: Behavioral response to contact with host feces. Journal of Chemical Ecology, 19, 1219-1231.

Grewal, P. S., Lewis, E. E., Gaugler, R., \& Campbell, J. F. (1994). Host finding behaviour as a predictor of foraging strategy in entomopathogenic nematodes. Parasitology, 108, 207-215.

Grewal, P. S., \& Peters, A. (2005). Formulation and quality. In P. S. Grewal, R.U. Ehlers, \& D. Shapiro-Ilan (Eds.), Nematodes as Biocontrol Agents, (pp. 79-90). Wallingford, UK: CAB International.

Griffin, C. T. (1996). Effects of prior storage conditions on the infectivity of Heterorhabditis sp. (Nematoda: Heterorhabditidae). Fundamental and Applied Nematology, 19, 95-102.

Griffin, C. T. (2012). Perspectives on the behavior of entomopathogenic nematodes from dispersal to reproduction: traits contributing to nematode fitness and biocontrol efficacy. Journal of Nematology, 44, 177-184.

Griffin, C. T., Finnegan, M. M., \& Downes, M. J. (1994). Environmental tolerances and the dispersal of Heterorhabditis: Survival and infectivity of european Heterorhabditis following prolonged immersion in seawater. Fundamental and Applied Nematology, 17, 415-421.

Griffin, C. T., O'Callaghan, K., \& Dix, I. (2001). A self-fertile species of Steinernema from Indonesia: Further evidence of convergent evolution amongst entomopathogenic nematodes? Parasitology, 122, 181-186.

Haas, W. (2003). Parasitic worms: Strategies of host finding, recognition and invasion. Zoology, 106, 349-364.

Hallem, E. A., Dillman, A. R., Hong, A. V., Zhang, Y. J., Yano, J. M., DeMarco, S. F., et al. (2011). A sensory code for host seeking in parasitic nematodes. Current Biology, 21, 377-383.

Hamilton, W. D. (1971). Geometry for the selfish herd. Journal of Theoretical Biology, 31, 295311.

Han, R. C., \& Ehlers, R. U. (2000). Pathogenicity, development, and reproduction of Heterorhabditis bacteriophora and Steinernema carpocapsae under axenic in vivo conditions. Journal of Invertebrate Pathology, 75, 55-58.

Hara, A. H., \& Kaya, H. K. (1983). Development of the entomogenous nematode, Neoaplectana carpocapsae (Rhabditida: Steinernematidae), in insecticide killed beet armyworm (Lepidoptera: Noctuidae). Journal of Economic Entomology, 76, 423-426.

Harvey, C. D., Alameen, K. M., \& Griffin, C. T. (2012). The impact of entomopathogenic nematodes on a non-target, service-providing longhorn beetle is limited by targeted application when controlling forestry pest Hylobius abietis. Biological Control, 62, 173-182.

Harvey, C. D., \& Griffin, C. T. (2012). Host activity and wasp experience affect parasitoid wasp foraging behaviour and oviposition on nematode-infected larvae of the forestry pest Hylobius abietis. Ecological Entomology, 37, 269-282.

Hass, B., Downes, M. J., \& Griffin, C. T. (2002). Persistence of four Heterorhabditis spp. isolates in soil: Role of lipid reserves. Journal of Nematology, 34, 151-158. 
Hass, B., Griffin, C. T., \& Downes, M. J. (1999). Persistence of Heterorhabditis infective juveniles in soil: Comparison of extraction and infectivity measurements. Journal of Nematology, 31, 508-516.

Hawkins, B. A., Cornell, H. V., \& Hochberg, M. E. (1997). Predators, parasitoids, and pathogens as mortality agents in phytophagous insect populations. Ecology, 78, 2145-2152.

Hawlena, H., Bashey, F., Mendes-Soares, H., \& Lively, C. M. (2010). Spiteful interactions in a natural population of the bacterium Xenorhabdus bovienii. American Naturalist, 175, 374-381.

Head, J., Palmer, L. F., \& Walters, K. E. (2003). The compatibility of control agents used for the control of the South American leafminer, Liriomyza huidobrensis. Biocontrol Science and Technology, 13, 77-86.

Hiltpold, I., Baroni, M., Toepfer, S., Kuhlmann, U., \& Turlings, T. C. J. (2010). Selection of entomopathogenic nematodes for enhanced responsiveness to a volatile root signal helps to control a major root pest. Journal of Experimental Biology, 213, 2417-2423.

Hiltpold, I., \& Turlings, T. C. J. (2008). Belowground chemical signaling in maize: When simplicity rhymes with efficiency. Journal of Chemical Ecology, 34, 628-635.

Hinsinger, P., Bengough, A. G., Vetterlein, D., \& Young, I. M. (2009). Rhizosphere: Biophysics, biogeochemistry and ecological relevance. Plant and Soil, 321, 117-152.

Hodson, A. K., Siegel, J. P., \& Lewis, E. E. (2012). Ecological influence of the entomopathogenic nematode, Steinernema carpocapsae, on pistachio orchard soil arthropods. Pedobiologia, 55, $51-58$.

Hui, E., \& Webster, J. M. (2000). Influence of insect larvae and seedling roots on the hostfinding ability of Steinernema feltiae (Nematoda: Steinernematidae). Journal of Invertebrate Pathology, 75, 152-162.

Hunt, H. W., Wall, D. H., DeCrappeo, N. M., \& Brenner, J. S. (2001). A model for nematode locomotion in soil. Nematology, 3, 705-716.

Jabbour, R., \& Barbercheck, M. E. (2008). Soil and habitat complexity effects on movement of the entomopathogenic nematode Steinernema carpocapsae in maize. Biological Control, 47, $235-243$.

Jansson, R. K., Lecrone, S. H., \& Gaugler, R. (1993). Field efficacy and persistance of entomopathogenic nematodes (Rhabditida, Steinernematidae, Heterorhabditidae) for control of sweet-potato weevil (Coleoptera, Apionidae) in southern Florida. Journal of Economic Entomology, 86, 1055-1063.

Kanagy, J. M. N., \& Kaya, H. K. (1996). The possible role of marigold roots and alpha terthienyl in mediating host-finding by steinernematid nematodes. Nematologica, 42, 220-231.

Kaplan, F., Alborn, H. T., von Reuss, S. H., Ajredini, R., Ali, J. G., Akyazi, F., et al. (2012). Interspecific nematode signals regulate dispersal behavior. Plos One, 7, e38735.

Kaya, H. K. (1978). Interaction between Neoaplectana carpocapsae (Nematoda: Steinernematidae) and Apanteles militaris (Hymenoptera: Bracondiae), a parasitoid of the armyworm, Pseudaletia unipuncta. Journal of Invertebrate Pathology, 31, 358-364.

Kaya, H. K. (2002). Natural enemies and other antagonists. In R. Gaugler (Ed.), Entomopathogenic nematology (pp. 189-203). Wallingford, UK: CAB International.

Kaya, H. K., \& Burlando, T. M. (1989). Development of Steinernema feltiae (Rhabditidae: Steinernematidae) in diseased insect hosts. Journal of Invertebrate Pathology, 53, 164-168.

Kaya, H. K., Gaugler, R., \& Kung, S. P. (1990). Soil type and entomopathogenic nematode persistence. Journal of Invertebrate Pathology, 55, 401-406.

Kaya, H. K., \& Hotchkin, P. G. (1981). The nematode Neoaplectana carpocapsae Weiser and its effect on selected ichneumonid and braconid parasites. Environmental Entomology, 10, 474 478.

Kim, H. G., \& Alston, D. G. (2008). Potential of two entomopathogenic nematodes for suppression of plum curculio (Conotrachelus nenuphar, Coleoptera: Curculionidae) life stages in northern climates. Environmental Entomology, 37, 1272-1279. 
Kondo, E. (1989). Studies on the infectivity and propogation of entomogenous nematodes, Steinernema spp. (Rhabditida: Steinernematidae), in the common cutworm Spodoptera litura (Lepidoptera: Noctuidae). Bulletin of the Faculty of Agriculture, Saga University, 67, 1-88.

Koppenhöfer, A., Baur, M., Stock, P., Choo, H., Chinnasri, B., \& Kaya, H. (1997). Survival of entomopathogenic nematodes within host cadavers in dry soil. Applied Soil Ecology, 6, 231-240.

Koppenhöfer, A. M., Campbell, J. F., Kaya, H. K., \& Gaugler, R. (1998). Estimation of entomopathogenic nematodes population density in soil by correlation between bait inset mortality and nematode penetration. Fundamental and Applied Nematology, 21, 95-102.

Koppenhöfer, A. M., Cowles, R. S., Cowles, E. A., Fuzy, E. M., \& Kaya, H. K. (2003). Effect of neonicotinoid synergists on entomopathogenic nematode fitness. Entomologia Experimentalis et Applicata, 106, 7-18.

Koppenhöfer, A. M., \& Fuzy, E. M. (2006). Effect of soil type on infectivity and persistence of the entomopathogenic nematodes Steinernema scarabaei, Steinernema glaseri, Heterorhabditis zealandica, and Heterorhabditis bacteriophora. Journal of Invertebrate Pathology, 92, 11-22.

Koppenhöfer, A. M., \& Fuzy, E. M. (2009). Long-term effects and persistence of Steinernema scarabaei applied for suppression of Anomala orientalis (Coleoptera: Scarabaeidae). Biological Control, 48, 63-72.

Koppenhöfer, A. M., \& Kaya, H. K. (1995). Density-dependent effects on Steinernema glaseri (Nematoda: Steinernematidae) within an insect host. Journal of Parasitology, 81, 797-799.

Koppenhöfer, A. M., Kaya, H. K., Shanmugam, S., \& Wood, G. L. (1995). Interspecific competition between steinernematid nematodes within an insect host. Journal of Invertebrate Pathology, 66, 99-103.

Kruitbos, L. M., Heritage, S., Hapca, S., \& Wilson, M. J. (2010). The influence of habitat quality on the foraging strategies of the entomopathogenic nematodes Steinernema carpocapsae and Heterorhabditis megidis. Parasitology, 137, 303-309.

Kruitbos, L. M., Heritage, S., \& Wilson, M. J. (2009). Phoretic dispersal of entomopathogenic nematodes by Hylobius abietis. Nematology, 11, 419-427.

Kung, S. P., \& Gaugler, R. (1991). Effects of soil temperature, moisture, and relative humidity on entomopathogenic nematode persistence. Journal of Invertebrate Pathology, 57, 242-249.

Lacey, L. A., Kaya, H. K., \& Bettencourt, R. (1995). Dispersal of Steinernema glaseri (Nematoda: Steinernematidae) in adult Japanese beetles, Popillia japonica (Coleoptera: Scarabaeidae). Biocontrol Science and Technology, 5, 121-130.

Lacey, L. A., Unruh, T. R., \& Headrick, H. L. (2003). Interactions of two idiobiont parasitoids (Hymenoptera: Ichneumonidae) of codling moth (Lepidoptera: Tortricidae) with the entomopathogenic nematode Steinernema carpocapsae (Rhabditida: Steinernematidae). Journal of Invertebrate Pathology, 83, 230-239.

Lee, C. E. (2002). Evolutionary genetics of invasive species. Trends in Ecology \& Evolution, 17, 386-391.

Lee, H., Choi, M. K., Lee, D., Kim, H. S., Hwang, H., Kim, H., et al. (2012). Nictation, a dispersal behavior of the nematode Caenorhabditis elegans, is regulated by IL2 neurons. Nature Neuroscience, 15, 107-112.

Letourneau, D. K., Jedlicka, J. A., Bothwell, S. G., \& Moreno, C. R. (2009). Effects of natural enemy biodiversity on the suppression of arthropod herbivores in terrestrial ecosystems. Annual Review of Ecology, Evolution, and Systematics, 40, 573-592.

Lewis, E. E., Campbell, J., Griffin, C., Kaya, H., \& Peters, A. (2006). Behavioral ecology of entomopathogenic nematodes. Biological Control, 38, 66-79.

Lewis, E. E., \& Gaugler, R. (1994). Entomopathogenic nematode (Rhabdita: Steinernemat idae) sex ratio relates to foraging strategy. Journal of Invertebrate Pathology, 64, 238-242.

Lewis, E. E., Gaugler, R., \& Harrison, R. (1993). Response of cruiser and ambusher entomopathogenic nematodes (Steinernematidae) to host volatile cues. Canadian Journal of Zoology-Revue Canadienne De Zoologie, 71, 765-769.

Lewis, E. E., Grewal, P. S., \& Gaugler, R. (1995). Hierarchical order of host cues in parasite foraging strategies. Parasitology, 119, 207-213. 
Lewis, E. E., Ricci, M., \& Gaugler, R. (1996). Host recognition behaviour predicts host suitability in the entomopathogenic nematode Steinernema carpocapsae (Rhabditida: Steinernematidae). Parasitology, 113, 573-579.

Lewis, E. E., \& Shapiro-Ilan, D. I. (2002). Host cadavers protect entomopathogenic nematodes during freezing. Journal of Invertebrate Pathology, 81, 25-32.

Lindegren, J. E., Valero, K. A., \& Mackey, B. E. (1993). Simple in vivo production and storage methods for Steinernema carpocapsae infective juveniles. Journal of Nematology, 25, 193-197.

MacInnis, A. J. (1976). How parasites find hosts: Some thoughts on the inception of host-parasite integration. In C. R. Kennedy (Ed.), Ecological aspects of parasitology (pp. 3-20). Amsterdam: North-Holland.

Mankin, R. W., Brandhorst-Hubbard, J., Flanders, K. L., Zhang, M., Crocker, R. L., Lapointe, S. L., et al. (2000). Eavesdropping on insects hidden in soil and interior structures of plants. Journal of Economic Entomology, 93, 1173-1182.

Mbata, G. N., \& Shapiro-Ilan, D. I. (2010). Compatibility of Heterorhabditis indica (Rhabditida: Heterorhabditidae) and Habrobracon hebetor (Hymenoptera: Braconidae) for biological control of Plodia interpunctella (Lepidoptera: Pyralidae). Biological Control, 54, 75-82.

McGraw, B. A., Vittum, P. J., Cowles, R. S., \& Koppenhöfer, A. M. (2010). Field evaluation of entomopathogenic nematodes for the biological control of the annual bluegrass weevil, Listronotus maculicollis (Coleoptera: Curculionidae), in golf course turfgrass. Biocontrol Science and Technology, 20, 149-163.

McNamara, J. M., \& Houston, A. I. (1991). Starvation and predation in a patchy environment. In B. Shorrocks \& I. R. Swingland (Eds.), Living in a patchy environment (pp. 23-43). Oxford: Oxford University Press.

McNeill, M., Phillips, C., Young, S., Shah, F., Aalders, L., Bell, N., et al. (2011). Transportation of nonindigenous species via soil on international aircraft passengers' footwear. Biological Invasions, 13, 2799-2815.

Mertz, N. R., Agudelo, E. J. G., Sales, F. S., Rohde, C., \& Moino, A. (2014). Phoretic dispersal of the entomopathogenic nematode Heterorhabditis amazonensis by the beetle Calosoma granulatum. Phytoparasitica, 42, 179-187.

Millar, L. C., \& Barbercheck, M. E. (2001). Interaction between endemic and introduced entomopathogenic nematodes in conventional-till and no-till corn. Biological Control, 22, $235-245$.

Molyneux, A. S. (1985). Survival of infective juveniles of Heterorhabditis spp., and Steinernema spp. (Nematoda: Rhabditida) at various temperatures and their subsequent infectivity for insects. Revue de Nematologie, 8, 165-170.

Morgan, K., McGaughran, A., Ganeshan, S., Herrmann, M., \& Sommer, R. J. (2014). Landscape and oceanic barriers shape dispersal and population structure in the island nematode Pristionchus pacificus. Biological Journal of the Linnean Society, 112, 1-15.

Mráček, Z., \& Spitzer, K. (1983). Interaction of the predators and parasitoids of the sawfly, Cephalcia abietis (Pamphilidae: Hymenoptera) with its nematode Steinernema kraussei. Journal of Invertebrate Pathology, 42, 397-399.

Nathan, R., Katul, G. G., Horn, H. S., Thomas, S. M., Oren, R., Avissar, R., et al. (2002). Mechanisms of long-distance dispersal of seeds by wind. Nature, 418, 409-413.

Nguyen, K. B., \& Smart, G. C. J. (1995). Morphometrics of infective juveniles of Steinernema spp. and Heterorhabditis bacteriophora (Nemata: Rhabditida). Journal of Nematology, 27, 206212.

Nielsen, A. L., \& Lewis, E. E. (2011). Designing the ideal habitat for entomopathogen use in nursery production. Pest Management Science, 68, 1053-1061.

Nielsen, O., \& Philipsen, H. (2004a). Recycling of entomopathogenic nematodes in Delia radicum and in other insects from cruciferous crops. BioControl, 49, 285-294.

Nielsen, O., \& Philipsen, H. (2004b). Seasonal population dynamics of inoculated and indigenous steinernematid nematodes in an organic cropping system. Nematology, 6, 901-909. 
Nkem, J. N., Wall, D. H., Virginia, R. A., Barrett, J. E., Broos, E. J., Porazinska, D. L., et al. (2006). Wind dispersal of soil invertebrates in the McMurdo Dry valleys, Antarctica. Polar Biology, 29, 346-352.

O’Callaghan, K. M., Zenner, A. N. R. L., Hartley, C. J., \& Griffin, C. T. (2014). Interference competition in entomopathogenic nematodes: Male Steinernema kill members of their own and other species. International Journal for Parasitology, 44, 1009-1017.

O'Leary, S., Power, P., Stack, C., \& Burnell, A. (2001). Behavioural and physiological responses of infective juveniles of the entomopathogenic nematode Heterorhabditis to desiccation. BioControl, 46, 345-362.

Parkman, J. P., \& Smart, G. C. (1996). Entomopathogenic nematodes, a case study: Introduction of Steinernema scapterisci in Florida. Biocontrol Science and Technology, 6, 413-419.

Patel, M. N., Stolinski, M., \& Wright, D. J. (1997). Neutral lipids and the assessment of infectivity in entomopathogenic nematodes: Observations on four Steinernema species. Parasitology, 114, 489-496.

Patel, M. N., \& Wright, D. J. (1997). Glycogen: Its importance in the infectivity of aged juveniles of Steinernema carpocapsae. Parasitology, 114, 591-596.

Peters, A. (1996). The natural host range of Steinernema and Heterorhabditis spp. and their impact on insect populations. Biocontrol Science and Technology, 6, 389-402.

Peters, A., \& Ehlers, R. U. (1994). Susceptibility of leatherjackets (Tipula paludosa and Tipula oleracea; Tipulidae: Nematocera) to the entomopathogenic nematode Steinernema feltiae. Journal of Invertebrate Pathology, 63, 163-171.

Pilz, C., Toepfer, S., Knuth, P., Strimitzer, T., Heimbach, U., \& Grabenweger, G. (2014). Persistence of the entomoparasitic nematode Heterorhabditis bacteriophora in maize fields. Journal of Applied Entomology, 138, 202-212.

Poinar, G. O., \& Hom, A. (1986). Survival and horizontal movement of infective stage Neoaplectana carpocapsae in the field. Journal of Nematology, 18, 34-36.

Portillo-Aguilar, C., Villani, M. G., Tauber, M. J., Tauber, C. A., \& Nyrop, J. P. (1999). Entomopathogenic nematode (Rhabditida: Heterorhabditidae and Steinernematidae) response to soil texture and bulk density. Environmental Entomology, 28, 1021-1035.

Preisser, E. L., Dugaw, C. J., Dennis, B., \& Strong, D. R. (2005). Long-term survival of the entomopathogenic nematode Heterorhabditis marelatus. Environmental Entomology, 34, 1501-1506.

Preisser, E. L., Dugaw, C. J., Dennis, B., \& Strong, D. R. (2006). Plant facilitation of a belowground predator. Ecology, 87, 1116-1123.

Prentis, P. J., Wilson, J. R. U., Dormontt, E. E., Richardson, D. M., \& Lowe, A. J. (2008). Adaptive evolution in invasive species. Trends in Plant Science, 13, 288-294.

Půža, V., \& Mráček, Z. (2007). Natural population dynamics of entomopathogenic nematode Steinernema affine (Steinernematidae) under dry conditions: Possible nematode persistence within host cadavers? Journal of Invertebrate Pathology, 96, 89-92.

Půža, V., \& Mráček, Z. (2009). Mixed infection of Galleria mellonella with two entomopathogenic nematode (Nematoda: Rhabditida) species: Steinernema affine benefits from the presence of Steinernema kraussei. Journal of Invertebrate Pathology, 102, 40-43.

Půža, V., \& Mráček, Z. (2010a). Does scavenging extend the host range of entomopathogenic nematodes (Nematoda: Steinernematidae)? Journal of Invertebrate Pathology, 104, 1-3.

Půža, V., \& Mráček, Z. (2010b). Mechanisms of coexistence of two sympatric entomopathogenic nematodes, Steinernema affine and S. kraussei (Nematoda: Steinernematidae), in a central European oak woodland soil. Applied Soil Ecology, 45, 65-70.

Pye, K. (1983). Coastal dunes. Progress in Physical Geography, 7, 531-557.

Ram, K., Gruner, D. S., McLaughlin, J. P., Preisser, E. L., \& Strong, D. R. (2008). Dynamics of a subterranean trophic cascade in space and time. Journal of Nematology, 40, 85-92.

Ram, K., Preisser, E. L., Gruner, D. S., \& Strong, D. R. (2008). Metapopulation dynamics override local limits on long-term parasite persistence. Ecology, 89, 3290-3297. 
Ramos-Rodriguez, O., Campbell, J. F., Christen, J. M., Shapiro-Ilan, D. I., Lewis, E. E., \& Ramaswamy, S. B. (2007). Attraction behaviour of three entomopathogenic nematode species towards infected and uninfected hosts. Parasitology, 134, 729-738.

Randall, J., Cable, J., Guschina, I. A., Harwood, J. L., \& Lello, J. (2013). Endemic infection reduces transmission potential of an epidemic parasite during co-infection. Proceedings of the Royal Society B-Biological Sciences, 280, 20131500.

Rasmann, S., Kollner, T. G., Degenhardt, J., Hiltpold, I., Toepfer, S., Kuhlmann, U., et al. (2005). Recruitment of entomopathogenic nematodes by insect-damaged maize roots. Nature, 434, 732-737.

Rasmann, S., \& Turlings, T. C. J. (2008). First insights into specificity of belowground tritrophic interactions. Oikos, 117, 362-369.

Rogers, C., Persson, A., Cheung, B., \& de Bono, M. (2006). Behavioral motifs and neural pathways coordinating $\mathrm{O}_{2}$ responses and aggregation in C. elegans. Current Biology, 16, 649-659.

Rolston, A., Meade, C., Boyle, S., Kakouli-Duarte, T., \& Downes, M. (2009). Intraspecific variation among isolates of the entomopathogenic nematode Steinernema feltiae from Bull Island, Ireland. Nematology, 11, 439-451.

Rolston, A. N., Griffin, C. T., \& Downes, M. J. (2006). Emergence and dispersal patterns of two isolates of the entomopathogenic nematode Steinernema feltiae. Journal of Nematology, 38, 221-228.

Ronce, O. (2007). How does it feel to be like a rolling stone? Ten questions about dispersal evolution. Annual Review of Ecology, Evolution, and Systematics, 38, 231-253.

Rosenheim, J. A., Kaya, H. K., Ehler, L. E., Marois, J. J., \& Jaffee, B. A. (1995). Intraguild predation among biological-control agents: Theory and evidence. Biological Control, 5, 303335.

Ryder, J. J., \& Griffin, C. T. (2002). Density dependent fecundity and infective juvenile production in the entomopathogenic nematode, Heterorhabditis megidis. Parasitology, 125, 83-92.

Ryder, J. J., \& Griffin, C. T. (2003). Phased infectivity in Heterorhabditis megidis: The effects of infection density in the parental host and filial generation. International Journal for Parasitology, 33, 1013-1018.

San-Blas, E., \& Gowen, S. R. (2008). Facultative scavenging as a survival strategy of entomopathogenic nematodes. International Journal for Parasitology, 38, 85-91.

San-Blas, E., Gowen, S. R., \& Pembroke, B. (2008). Steinernema feltiae: Ammonia triggers the emergence of their infective juveniles. Experimental Parasitology, 119, 180-185.

Sax, D. F., Stachowicz, J. J., Brown, J. H., Bruno, J. F., Dawson, M. N., Gaines, S. D., et al. (2007). Ecological and evolutionary insights from species invasions. Trends in Ecology \& Evolution, $22,465-471$.

Scheepmaker, J. W. A., Geels, F. P., Griensven, L. J. L., Van, D., \& Smits, P. H. (1998). Susceptibility of larvae of the mushroom fly Megaselia halterata to the entomopathogenic nematode Steinernema feltiae in bioassays. BioControl, 43, 201-214.

Schroer, S., Yi, X. L., \& Ehlers, R. U. (2005). Evaluation of adjuvants for foliar application of Steinernema carpocapsae against larvae of the diamondback moth (Plutella xylostella). Nematology, 7, 37-44.

Selvan, S., Campbell, J. F., \& Gaugler, R. (1993). Density-dependent effects on entomopathogenic nematodes (Heterorhabditidae and Steinernematidae) within an insect host. Journal of Invertebrate Pathology, 62, 278-284.

Serwe-Rodriguez, J., Sonnenberg, K., Appleman, B., \& Bornstein-Forst, S. (2004). Effects of host desiccation on development, survival, and infectivity of entomopathogenic nematode Steinernema carpocapsae. Journal of Invertebrate Pathology, 85, 175-181.

Shannag, H. K., \& Capinera, J. L. (2000). Interference of Steinernema carpocapsae (Nematoda: Steinernematidae) with Cardiochiles diaphaniae (Hymenoptera: Braconidae), a parasitoid of melonworm and pickleworm (Lepidoptera: Pyralidae). Environmental Entomology, 29, 612-617.

Shapiro, D. I., \& Glazer, I. (1996). Comparison of entomopathogenic nematode dispersal from infected hosts versus aqueous suspension. Environmental Entomology, 25, 1455-1461. 
Shapiro, D. I., Glazer, I., \& Segal, D. (1996). Trait stability and fitness of the heat tolerant entomopathogenic nematode Heterorhabditis bacteriophora IS5 strain. Biological Control, 6, 238-244.

Shapiro, D. I., Glazer, I., \& Segal, D. (1997). Genetic diversity in wild and laboratory populations of Heterorhabditis bacteriophora as determined by RAPD-PCR analysis. Fundamental and Applied Nematology, 20, 581-585.

Shapiro, D. I., \& Lewis, E. E. (1999). Comparison of entomopathogenic nematode infectivity from infected hosts versus aqueous suspension. Environmental Entomology, 28, 907-911.

Shapiro, D. I., Tylka, G. L., Berry, E. C., \& Lewis, L. C. (1995). Effects of earthworms on the dispersal of Steinernema spp. Parasitology, 21, 21-28.

Shapiro, M., Poinar, G. O., \& Lindegren, J. E. (1985). Suitability of Lymantria dispar (Lepidoptera: Lymantriidae) as a host for the entomogeneous nematode, Steinernema feltiae (Rhabditida: Steinernematidae). Journal of Economic Entomology, 78, 342-345.

Shapiro-Ilan, D. I., Brown, I., \& Lewis, E. E. (2014). Freezing and desiccation tolerance in entomopathogenic nematodes: Diversity and correlation of traits. Journal of Nematology, 46, $27-34$.

Shapiro-Ilan, D. I., Dutcher, J. D., \& Hatab, M. (2005). Recycling potential and fitness of steinernematid nematodes cultured in Curculio caryae and Galleria mellonella. Journal of Nematology, 37, 12-17.

Shapiro-Ilan, D. I., Gaugler, R., Tedders, W. L., Brown, I., \& Lewis, E. E. (2002). Optimization of inoculation for in vivo production of entomopathogenic nematodes. Journal of Nematology, $34,343-350$.

Shapiro-Ilan, D. I., Han, R., \& Dolinski, C. (2012). Entomopathogenic nematode production and application technology. Journal of Nematology, 44, 226-235.

Shapiro-Ilan, D. I., Jackson, M., Reilly, C. C., \& Hotchkiss, M. W. (2004). Effects of combining an entomopathogenic fungi or bacterium with entomopathogenic nematodes on mortality of Curculio caryae (Coleoptera: Curculionidae). Biological Control, 30, 119-126.

Shapiro-Ilan, D. I., Lewis, E. E., \& Schliekelman, P. (2014). Aggregative group behavior in insect parasitic nematode dispersal. International Journal for Parasitology, 44, 49-54.

Sher, R. B., Parrella, M. P., \& Kaya, H. K. (2000). Biological control of the Leafminer Liriomyza trifolii (Burgess): Implications for intraguild predation between Diglyphus begini Ashmead and Steinernema carpocapsae (Weiser). Biological Control, 17, 155-163.

Shields, E. J., Testa, A., Miller, J. M., \& Flanders, K. L. (1999). Field efficacy and persistence of the entomopathogenic nematodes Heterorhabditis bacteroiophora 'Oswego' and H. bacteriophora "NC" on alfalfa snout beetle larvae (Coleoptera: Curculionidae). Environmental Entomology, $28,128-136$.

Sicard, M., Ferdy, J. B., Pages, S., Le Brun, N., Godelle, B., Boemare, N., et al. (2004). When mutualists are pathogens: An experimental study of the symbioses between Steinernema (entomopathogenic nematodes) and Xenorhabdus (bacteria). Journal of Evolutionary Biology, 17, 985-993.

Sicard, M., Hinsinger, J., Le Brun, N., Pages, S., Boemare, N., \& Moulia, C. (2006). Interspecific competition between entomopathogenic nematodes (Steinernema) is modified by their bacterial symbionts (Xenorhabdus). BMC Evolutionary Biology, 6, 68.

Sicard, M., Ramone, H., Le Brun, N., Pages, S., \& Moulia, C. (2005). Specialization of the entomopathogenic nematode Steinernema scapterisci with its mutualistic Xenorhabdus symbiont. Naturwissenschaften, 92, 472-476.

Simberloff, D. (2009). The role of propagule pressure in biological invasions. Annual Review of Ecology, Evolution, and Systematics, 40, 81-102.

Singh, S. K., Hodda, M., Ash, G. J., \& Banks, N. C. (2013). Plant-parasitic nematodes as invasive species: Characteristics, uncertainty and biosecurity implications. Annals of Applied Biology, $163,323-350$.

Smits, P. H. (1996). Post-application persistence of entomopathogenic nematodes. Biocontrol Science and Technology, 6, 379-387. 
Somasekhar, N., Grewal, P. S., \& Klein, M. G. (2002). Genetic variability in stress tolerance and fitness among natural populations of Steinernema carpocapsae. Biological Control, 23, 303-310.

Spence, K. O., Stevens, G. N., Arimoto, H., Ruiz-Vega, J., Kaya, H. K., \& Lewis, E. E. (2011). Effect of insect cadaver desiccation and soil water potential during rehydration on entomopathogenic nematode (Rhabditida: Steinernematidae and Heterorhabditidae) production and virulence. Journal of Invertebrate Pathology, 106, 268-273.

Spiridonov, S. E., Moens, M., \& Wilson, M. J. (2007). Fine scale spatial distributions of two entomopathogenic nematodes in a grassland soil. Applied Soil Ecology, 37, 192-201.

Strong, D. R. (2002). Populations of entomopathogenic nematodes in foodwebs. In R. Gaugler (Ed.), Entomopathogenic nematology (pp. 225-240). Wallingford, UK: CAB International.

Strong, D. R., Kaya, H. K., Whipple, A. V., Child, A. L., Kraig, S., Bondonno, M., et al. (1996). Entomopathogenic nematodes: Natural enemies of root-feeding caterpillars on bush lupine. Oecologia, 108, 167-173.

Stuart, R. J., Barbercheck, M. E., Grewal, P. S., Taylor, R. A. J., \& Hoy, C. W. (2006). Population biology of entomopathogenic nematodes: Concepts, issues, and models. Biological Control, $38,80-102$.

Stuart, R. J., Lewis, E. E., \& Gaugler, R. (1996). Selection alters the pattern of emergence from the host cadaver in the entomopathogenic neatode, Steinernema glaseri. Parasitology, 113, 183189.

Sudhaus, W. (2008). Evolution of insect parasitism in rhabditid and diplogastrid nematodes. Papers dedicated to Prof. Dr Bozidar Curcic. In S. E. Markarov \& R. N. Dimittrijevic (Eds.), Advances in arachnology and developmental biology (pp. 143-161). Belgrade, Serbia: Institute of Zoology, Faculty of Biology, University of Belgrade.

Sukhdeo, M. V. K., \& Sukhdeo, S. C. (2004). Trematode behaviours and the perceptual worlds of parasites. Canadian Journal of Zoology-Revue Canadienne De Zoologie, 82, 292-315.

Susurluk, A., \& Ehlers, R. U. (2008). Field persistence of the entomopathogenic nematode Heterorhabditis bacteriophora in different crops. BioControl, 53, 627-641.

Taylor, D. B., Szalanski, A. L., Adams, B. J., \& Peterson, R. D. (1998). Susceptibility of house fly (Diptera: Muscidae) larvae to entomopathogenic nematodes (Rhabditida: Heterorhabditidae, Steinernematidae). Environmental Entomology, 27, 1514-1519.

Thornton, D. C. O. (1999). Phytoplankton mucilage production in coastal waters: A dispersal mechanism in a front dominated system? Ethology Ecology \& Evolution, 11, 179-185.

Timper, P., Kaya, H. K., \& Gaugler, R. (1988). Dispersal of the entomogenous nematode Steinernema feltiae (Rhabditida: Steinernematidae) by infected adult insects. Environmental Entomology, 17, 546-550.

Torr, P., Heritage, S., \& Wilson, M. J. (2004). Vibrations as a novel signal for host location by parasitic nematodes. International Journal for Parasitology, 34, 997-999.

Torr, P., Wilson, M. J., \& Heritage, S. (2005). Forestry applications. In P. S. Grewal, R.-U. Ehlers, \& D. I. Shapiro-Ilan (Eds.), Nematodes as biocontrol agents (pp. 281-293). Wallingford, UK: $\mathrm{CAB}$ International.

Turlings, T. C. J., Hiltpold, I., \& Rasmann, S. (2012). The importance of root-produced volatiles as foraging cues for entomopathogenic nematodes. Plant and Soil, 358, 47-56.

van Tol, R., van der Sommen, A. T. C., Boff, M. I. C., van Bezooijen, J., Sabelis, M. W., \& Smits, P. H. (2001). Plants protect their roots by alerting the enemies of grubs. Ecology Letters, 4, 292-294.

Wallace, H. R. (1968). Dynamics of nematode movement. Annual Review of Phytopathology, 6, 91-114.

Wallwork, J. A. (1970). Ecology of soil animals. London: McGraw Hill.

Wang, H., Jung, Y. H., Son, D., \& Choo, H. Y. (2013). High level of genetic diversity among Steinernema monticolum in Korea revealed by single-enzyme amplified fragment length polymorphism. Journal of Invertebrate Pathology, 113, 146-151.

Wang, Y., \& Gaugler, R. (1998). Host and penetration site location by entomopathogenic nematodes against Japanese beetle larvae. Journal of Invertebrate Pathology, 72, 313-318. 
Williams, C. D., Dillon, A. B., Girling, R. D., \& Griffin, C. T. (2013). Organic soils promote the efficacy of entomopathogenic nematodes, with different foraging strategies, in the control of a major forest pest: A meta-analysis of field trial data. Biological Control, 65, 357-364.

Williams, E. C., \& Macdonald, O. C. (1995). Critical factors required by the nematode Steinernema feltiae for the control of the leafminers Liriomyza huidobrensis, Liriomyza bryoniae and Chromatomyia syngenesiae. Annals of Applied Biology, 127, 329-341.

Wilson, M., \& Gaugler, R. (2004). Factors limiting short-term persistence of entomopathogenic nematodes. Journal of Applied Entomology, 128, 250-253.

Wilson, M. J., Ehlers, R.-U., \& Glazer, I. (2012). Entomopathogenic nematode foraging strategies is Steinernema carpocapsae really an ambush forager? Nematology, 14, 389-394.

Wright, C. A. (1959). Host location by trematode miracidia. Annals of Tropical Medicine and Parasitology, 53, 288-292.

Wright, D. J., Peters, A., Schroer, S., \& Fife, J. P. (2005). Application technology. In P. S. Grewal, R. U. Ehlers, \& D. Shapiro-Ilan (Eds.), Nematodes as biocontrol agents (pp. 91-106). Wallingford, UK: CAB International.

Wuyts, N., Maung, Z. T. Z., Swennen, R., \& De Waele, D. (2006). Banana rhizodeposition: Characterization of root border cell production and effects on chemotaxis and motility of the parasitic nematode Radopholus similis. Plant and Soil, 283, 217-228.

Yang, Y. Z., Elgeti, J., \& Gompper, G. (2008). Cooperation of sperm in two dimensions: Synchronization, attraction, and aggregation through hydrodynamic interactions. Physical Review E, 78, 061903.

Yang, Y. Z., Marceau, V., \& Gompper, G. (2010). Swarm behavior of self-propelled rods and swimming flagella. Physical Review E, 82, 031904.

Yuan, J. Z., Raizen, D. M., \& Bau, H. H. (2014). Gait synchronization in Caenorhabditis elegans. Proceedings of the National Academy of Sciences of the United States of America, 111, 6865-6870.

Zadji, L., Baimey, H., Afouda, L., Moens, M., \& Decraemer, W. (2014). Comparative susceptibility of Macrotermes bellicosus and Trinervitermes occidentalis (Isoptera: Termitidae) to entomopathogenic nematodes from Benin. Nematology, 16, 719-727.

Zenner, A. N. R. L., O'Callaghan, K., \& Griffin, C. T. (2014). Lethal fighting in nematodes is dependent on developmental pathway: Male-male fighting in the entomopathogenic nematode Steinernema longicaudum. PloS One, 9, e89385.

Zervos, S., Johnson, S. C., \& Webster, J. M. (1991). Effect of temperature and inoculum size on reproduction and development of Heterorhabditis heliothidis and Steinerema glaseri (Nematoda: Rhabditoidea) in Galleria mellonella. Canadian Journal of Zoology, 69, 12611264.

Zimmerman, R. J., \& Cranshaw, W. S. (1991). Short-term movement of Neoaplectana spp (Rhabditida, Steinernematidae) and Heterorhabditis HP-88 Strain (Rhabditida, Heterorhabditidae) through turfgrass thatch. Journal of Economic Entomology, 84, 875-878. 